\title{
Influence of tied-ridge with biochar amendment on runoff, sediment losses, and alfalfa yield in northwestern China
}

\author{
Erastus Mak-Mensah ${ }^{1}$, Faisal Eudes Sam ${ }^{2}$, Itoba Ongagna Ipaka Safnat Kaito ${ }^{3}$, Wucheng Zhao ${ }^{1}$, Dengkui Zhang ${ }^{1}$, \\ Xujiao Zhou ${ }^{1}$, Xiaoyun Wang ${ }^{1}$, Xiaole Zhao ${ }^{1}$, Qi Wang ${ }^{\text {Corresp. } 1}$ \\ ${ }^{1}$ College of Grassland Science, Gansu Agricultural University, Lanzhou, Gansu Province, China \\ ${ }^{2}$ College of Food Science and Engineering, Gansu Agricultural University, Gansu Key Laboratory of Viticulture and Enology, Lanzhou, Gansu Province, \\ China \\ ${ }^{3}$ College of Science, Gansu Agricultural University, Lanzhou, Gansu Province, China \\ Corresponding Author: Qi Wang \\ Email address: 2873527446@qq.com
}

Background: Loss of organic matter and mineral nutrients to soil erosion in rain-fed agriculture is a serious problem globally, especially in China's Loess Plateau. As a result, increasing rainwater usage efficiency by tied-ridge-furrow rainwater harvesting with biochar is expected to improve agricultural productivity. Nonetheless, with limited knowledge on tied-ridge-furrow rainwater harvesting with biochar, small-scale farmers face the challenge of adoption, thus, the rationale for this study.

Materials and methods: A field experiment was conducted to determine the influence of open-ridging (OR) and tied-ridging (TR) with bio-degradable film on ridges and biochar in furrows on runoff, sediment losses, soil moisture, fodder yield, and water use efficiency (WUE) on sloped land, using flat planting (FP) without ridges and furrows as control, during alfalfa-growing year (2020).

Results: Runoff in flat planting (30\%), open ridging (45\%), and tied ridging (52\%) were decreased with biochar to the extent where sediment was decreased in flat planting (33\%), open ridging (43\%), and tied ridging (44\%) as well. The mean runoff efficiency was lower in flat planting (31\%), open ridging (45\%), and tied ridging $(50 \%)$ in biochar plots compared to no-biochar plots. In biochar and no-biochar plots, soil temperature on ridges of TR was higher than that on OR, which was higher than FP during alfalfa growing season. Soil temperature in furrows during alfalfa growing season in biochar and no-biochar plots were in the order FP > OR > TR. Mean soil water storage for FP, OR, and TR, in biochar plots was higher than in no-biochar plots. This indicates biochar has a beneficial impact on open riding. Total annual net fodder yield (NFY) was significantly $(p=0.00)$ higher in treatments in the order TR $>$ OR $>$ FP. Tied ridging had a significant effect on actual fodder yield (AFY) in biochar plots, while open ridging significantly affected AFY in no-biochar plots. Annual total mean NFY and AFY increased by $8 \%$ and $11 \%$ in biochar plots compared to no-biochar plots. In biochar and no-biochar plots, water use efficiency was in the order TR > OR > FP. Conclusively, water use efficiency was significantly higher $(p=0.01)$ in biochar plots compared to no-biochar plots.

Conclusion: When crop production is threatened by soil erosion and drought, mulched tied-ridge with biochar is beneficial to crop growth in rain-fed agriculture, according to this research. Smallholder farmers should be trained on applying this technique for water-saving to mitigate runoff, soil erosion, sediment losses, and improve food security in semiarid areas. 


\title{
Influence of tied-ridge with biochar amendment on runoff, sediment losses, and alfalfa yield in northwestern China.
}

\author{
Erastus Mak-Mensah ${ }^{1}$, Faisal Eudes $\mathrm{Sam}^{2}$, Itoba Ongagna Ipaka \\ Safnat Kaito ${ }^{3}$, Wucheng Zhao ${ }^{1}$, Dengkui Zhang ${ }^{1}$, Xujiao Zhou ${ }^{1}$, Xiaoyun Wang ${ }^{1}$, Xiaole \\ Zhao $^{1}$, Qi Wang ${ }^{*}$ \\ ${ }^{1}$ College of Grassland Science, Gansu Agricultural University, Lanzhou, China \\ ${ }^{2}$ College of Food Science and Engineering, Gansu Key Laboratory of Viticulture and Enology, \\ Gansu Agricultural University, Lanzhou, China \\ ${ }^{3}$ College of Science, Gansu Agricultural University, Lanzhou, China
}

\begin{abstract}
Correspondence: Qi Wang', Number 1 Yingmen Road, Anning District, Lanzhou, Gansu Province, China. Email address: 2873527446@qq.com.
\end{abstract}

\begin{abstract}
Background: Loss of organic matter and mineral nutrients to soil erosion in rain-fed agriculture is a serious problem globally, especially in China's Loess Plateau. As a result, increasing rainwater usage efficiency by tied-ridge-furrow rainwater harvesting with biochar is expected to improve agricultural productivity. Nonetheless, with limited knowledge on tied-ridge-furrow rainwater harvesting with biochar, small-scale farmers face the challenge of adoption, thus, the rationale for this study.

Materials and methods: A field experiment was conducted to determine the influence of openridging (OR) and tied-ridging (TR) with bio-degradable film on ridges and biochar in furrows on runoff, sediment losses, soil moisture, fodder yield, and water use efficiency (WUE) on sloped land, using flat planting (FP) without ridges and furrows as control, during alfalfa-growing year (2020).
\end{abstract}

Results: Runoff in flat planting (30\%), open ridging (45\%), and tied ridging (52\%) were decreased with biochar to the extent where sediment was decreased in flat planting (33\%), open ridging (43\%), and tied ridging (44\%) as well. The mean runoff efficiency was lower in flat planting (31\%), open ridging (45\%), and tied ridging (50\%) in biochar plots compared to nobiochar plots. In biochar and no-biochar plots, soil temperature on ridges of TR was higher than that on OR, which was higher than FP during alfalfa growing season. Soil temperature in furrows during alfalfa growing season in biochar and no-biochar plots were in the order FP $>$ OR $>$ TR. Mean soil water storage for FP, OR, and TR, in biochar plots was higher than in no-biochar plots. This indicates biochar has a beneficial impact on open riding. Total annual net fodder yield (NFY) was significantly $(\mathrm{p}=0.00)$ higher in treatments in the order TR $>$ OR $>$ FP. Tied ridging had a significant effect on actual fodder yield (AFY) in biochar plots, while open ridging 
significantly affected AFY in no-biochar plots. Annual total mean NFY and AFY increased by $8 \%$ and $11 \%$ in biochar plots compared to no-biochar plots. In biochar and no-biochar plots, water use efficiency was in the order TR $>\mathrm{OR}>\mathrm{FP}$. Conclusively, water use efficiency was significantly higher $(\mathrm{p}=0.01)$ in biochar plots compared to no-biochar plots.

Conclusion: When crop production is threatened by soil erosion and drought, mulched tied-ridge with biochar is beneficial to crop growth in rain-fed agriculture, according to this research. Smallholder farmers should be trained on applying this technique for water-saving to mitigate runoff, soil erosion, sediment losses, and improve food security in semiarid areas.

Keywords: Ridge-furrow rainwater harvesting, Tied ridging, Runoff, Sediment, Biochar, Alfalfa fodder yield

\section{Introduction}

The Loess Plateau of China is accustomed to unpredicted rainfall, with spatial variations accompanied by recurring droughts (Ding et al., 2018; Wang et al., 2015; Jin et al., 2007). In addition to these climatic conditions of the Loess Plateau, topography contributes immensely to severe soil erosion in events of heavy rainfall (Chen et al., 2019; Wang et al., 2016; Meng et al., 2008). Consistent soil erosion reduces soil nutrient and moisture availability for crops (Jin et al., 2007; Fu et al., 2004; Trimble \& Crosson, 2000). Thus, loss of soil nutrients destabilizes the structure and population of microbes in the soil (Xiao et al., 2017; Du et al., 2020). Consequently, alfalfa (Medicago sativa $L$.) was revealed as ideal for protecting soil hence, was commonly grown on the Loess Plateau (Jun et al., 2010). Soon after, alfalfa was discovered to be seriously depleting soil water in these areas, due to its deep roots' water absorption from deep soil layers (Jun et al., 2010). Fan et al. (2016) reported alfalfa can exhaust available soil water in a field in less than 6 years and prevent deep soil water recharge. Wang et al. (2012) corroborated this by revealing dry soil layers in deep soil after alfalfa cultivation which has significantly obstructed sustainable agriculture development. However, these fragile regions remain the main source of livelihood for millions of deprived and vulnerable people (Bado et al., 2021). On this account, agriculture in semiarid areas must be improved by increasing rainwater use efficiency with mulching in rainwater harvesting scheme (Meng et al., 2020).

In recent years, many field studies have revealed ridge and furrow rainwater harvesting (RFRH) as an effective and simple technique for increasing soil water content (SWC) and improving rainwater use efficiency in rain-fed agriculture (Li et al., 2016; Xiaolong et al., 2008). RFRH can gather effective or ineffective rainfall, prevent surface runoff during intensive rainfall, and reduce evaporation (Zheng et al., 2019; Jia et al., 2018; Liang et al., 2018; Han et al., 2013). RFRH is extensively practiced in areas with $<5 \mathrm{~mm}$ rainfall, where irrigation is not available (Liu et al., 2020) for improving rainfall infiltration and soil moisture (Ren et al., 2016), facilitating seedling growth at a faster pace (Gan et al., 2013; Zhang et al., 2011; Ramakrishna et al., 2006), and improving crop yield and maintaining food stability (Chen et al., 2015; Bu et al., 2013). RFRH has been demonstrated in many studies to increase soil temperature as compared to 
flat planting (Zhang et al., 2017; Mo et al., 2017). In extreme rainfall events, however, water runs over the ridges (Wiyo et al., 2000). Hence, building basins with cross-ties known as tiedridging, to store surface runoff in furrows is a solution to excess water flowing over ridges (overtopping) in RFRH on sloped lands (Vejchar et al., 2019). The collected water can be used by crops for a long time better than it can be used in the state of runoff (Ndlangamandla et al., 2016). The cross-ties also reduce the speed of the water flow along furrows (Mutiso, 2018) and often increase the length of crop growing seasons (Mason et al., 2015).

Previous studies have shown that tied-ridge, which is a proven method of maintaining soil moisture at $0-5$ and $6-10 \mathrm{~cm}$ soil depth in drier periods in rain-fed agriculture, increases yield by 50\% (Mandumbu et al., 2020; Sibhatu et al., 2017). Beshir \& Abdulkerim (2017) revealed an increase in soil fertility with in-furrow planting in a closed-end tied-ridge system. Consequently, Mupangwa et al. (2006) reported an average maize yield of $3400 \mathrm{~kg}$ ha-1 from tied ridges compared with $1500 \mathrm{~kg}$ ha-1 from conventionally ploughed fields. A study conducted by Brhane et al. (2006) revealed that variations in tied-ridging beneficial effects on crop yield are due to differences in distribution and amount of rainfall, slope, soil type, landscape position, time of ridging, and crop type. They further stated that soil water and sorghum grain yield was increased with tied-ridging by more than 25 and 40\%, respectively, as compared to conventional tillage (shilshalo) practice in northern Ethiopia. Tied-ridging has been effective in increasing soil water storage and decreasing runoff in Tanzania (Guzha, 2004), and the USA (Howell et al., 2000). However, inappropriate use of tied-ridging can lead to problems such as waterlogging, and total loss of crops in harsh storms (Brhane et al., 2006). Studies in arid and semiarid areas of sub-Saharan Africa suggested that single water conservation interventions could improve crop yields by up to 50\% (Araya \& Stroosnijder, 2010; Bennie \& Hensley, 2001; Walker et al., 2005) while combination of tied-ridges and nutrient inputs have accounted for two-fold to six-fold crop yields compared with conventional tillage practices without fertilizer use (Jensen et al., 2003; Zougmoré et al., 2003). Therefore, given the deficient soil fertility nature of arid and semiarid areas of northwestern China, single rainwater harvesting intervention may not bring about a considerable influence on crop productivity (Biazin \& Stroosnijder, 2012). Thus, tied ridging with mulching which has been widely practiced in many countries (Donjadee \& Tingsanchali, 2016; Chakraborty et al., 2008; Mupangwa et al., 2006) with a consistent increase in crop production should be explored. Mulching, a significant agronomic practice, is gaining considerable attention globally due to its phenomenal effect and low cost (Li et al., 2020). Mulching has different generally established environmental functions (Prosdocimi et al., 2016). Some of which are notably increasing soil surface coarseness hence decreasing runoff, sediment, and nutrient content in runoff (Vega et al., 2015; Lee et al., 2018). In addition, mulching retains soil moisture, hence increases rainfall infiltration and decreases evapotranspiration (Li et al., 2020). Decomposed mulching materials increase soil organic matter and available soil nutrients for crop development (Jiménez et al., 2016; Bajgai et al., 2014; Jordán et al., 2010). There have been significant reports on effectiveness of mulching in reducing soil water and nutrient loss in different climatic environments in America (Ruy et al., 2006), Europe (Fernández et al., 2012; 
119

120

121

122

123

124

125

126

127

128

129

130

131

132

133

134

135

136

137

138

139

140

141

142

143

144

145

146

147

148

149

150

151

152

153

154

155

156

157

158

Abrantes et al., 2018), Asia (Wang et al., 2016), and Africa (Mwango et al., 2016). One such prominent mulching technology is biochar amendment (Woolf et al., 2010; Woolf et al., 2018).

Biochar, a steady carbon-rich material manufactured from pyrolyzing biomass in oxygendeprived environments, can improve soil carbon sequestration and soil quality (Lehmann \& Rondon, 2006). A potential feedstock is shelled maize cobs crop residues, often burnt or left on the field in rural regions of developing countries to decompose (Silayo et al., 2016). By improving cation exchange capacity and soil structure, biochar increases soil fertility (Martinsen et al., 2014) and decreases nutrient leaching (Laird et al., 2010). Biochar became known as a key element of the popular fertile anthropogenic Terra Preta soil of Central Amazonia (Glaser \& Birk, 2012). Studies have confirmed biochar as extremely viable for curbing soil and nutrients losses on sloping lands in semiarid regions (Li et al., 2019; Zhang et al., 2017; Han et al., 2016; Xiao et al., 2016; Liu et al., 2012). For example, Kammann et al. (2012) discovered a significant increase in biomass in biochar-modified soils relative to controls in perennial ryegrass (Lolium perenne L.). Consequently, Rondon et al. (2007) revealed addition of biochar to a low-fertility soil led to $22 \%$ increased nitrogen fixation in beans (Phaseolus vulgaris) in addition to significantly improved biomass and bean yield. In terms of runoff and erosion, biochar can help increase infiltration rate and saturated hydraulic conductivity (Ksat) in clayey soils thereby curbing erosion, flooding, and contamination of streams (Li et al., 2019; Li et al., 2018; Obia et al., 2018; Lim et al., 2016). Saturated hydraulic conductivity is the ease of water flow through the soil when it is saturated and it is vital for flooding, drainage, and soil water studies (Lu, 2015; Kirkham, 2014). Biochar has also been recounted to improve soil physical and hydrological properties, ranging from bulk density and soil porosity to soil aggregate stability (Fischer et al., 2019; Burrell et al., 2016; Głąb et al., 2016). Biochar amendment, in combination with a slow decomposition (Peng et al., 2011; Wang et al., 2016), foster carbon sequestration and long-term soil improvements (Kuzyakov et al., 2014; Lehmann et al., 2008), and thus can aid in mitigating climate change (Crane-Droesch et al., 2013; Woolf et al., 2010). Jeffery et al. (2017) discovered in a meta-analysis that extremely predominantly weathered soils, prevalent in the humid tropics, benefit from biochar amendments with mean crop yield increases of $25 \%$. Meanwhile, in some other studies, biochar has been demonstrated not to influence soil moisture. Hardie et al. (2014) recounted that 30 months after biochar amendments to a sandy loam soil, no significant outcome was revealed on soil moisture at various tensions (measurement of the quantity of energy necessary to transport water in the soil). Conversely, Gonzaga et al. (2018) found that soils treated with $30 \mathrm{t} \mathrm{ha}^{-1}$ coconut husk biochar increased $90 \%$ of Zea mays biomass, while orange bagasse biochar applied at the same concentration had no impact. The disparity in outcomes from different studies, however, could be ascribed to differences in soil types, plant species treated, biochar application rates, and experimental circumstances (Edeh et al., 2020; Nooker, 2014).

In a recent study, Anyanwu et al. (2018) found aged biochar in soil has a detrimental impact on earthworms and/or fungi growth. Furthermore, this resulted in a decrease in rice (Oryza sativa) and Tomato (Solanum lycopersicum) underground root biomass. In addition, 
159 biochar has been shown to reduce soil thermal diffusivity due to biochar's low thermal diffusivity 160 (Zhao et al., 2016). Biochar's beneficial effects are shown to be soil specific, contrary to common 161 belief. As a result, biochar amendment could not be beneficial to all forms of soil (Zhu et al., 162 2015). Nevertheless, when biochars were used, several studies identified weed problems. 163 Biochar application at relatively high rates of $15 \mathrm{t} \mathrm{ha}^{-1}$ resulted in a 200\% increase in weed

164 growth during lentil culture, according to Safaei Khorram et al. (2018); suggesting repeated biochar applications might not be good for weed control. According to Vaccari et al. (2015), applying $14 \mathrm{t} \mathrm{ha}^{-1}$ of biochar to tomato plants improved vegetative growth but not fruit yield. Instead of providing plant nutrients, biochar can react with soil nutrients and function as a competitor (Joseph et al., 2018). Biochar can adsorb nitrogen as well as essential nutrients like Fe, which can be detrimental to plant development (Kim et al., 2015), since this may delay plant flowering (Hol et al., 2017). Biochar amendments in saline sodic soil could aid phosphate precipitation and sorption reactions which could ultimately lead to a reduction in amount of phosphorus available to plants (Xu et al., 2016). Concurrently, biochar amendment in soil, for example, had no effect on pesticide absorption of dichlorodiphenyltrichloroethane (DDT) (Denyes et al., 2016). In terms of soil biology, biochar can disrupt organic matter decomposition, reducing abundance of fungi species such as Ascomycota and Basidiomycota by 11 and $66 \%$, respectively (Zheng et al., 2016). Despite several studies showing biochar amendment has positive and negative effects, there is still a lot of confusion regarding effects in conjunction with other management techniques (Solaiman \& Anawar, 2015).

Although biochar amendment (Solaiman \& Anawar, 2015), and tied-ridging (Twomlow \& Bruneau, 2000) has widely been explored, conflicting reports on the effects in conjunction with other management techniques are prevalent. In addition, most studies report on only yield advantages, ignoring trade-offs between runoff, sediment losses, soil temperature, and moisture (Ademe et al., 2018). Therefore, there is the need for investigations into the combined effects of tied-ridge as a field soil moisture conservation technique with biochar on sloped land is needed to allow this know-how to be better situated to compete with other droughts, and soil erosion mitigation approaches (Woolf et al., 2016; Woolf et al., 2018). To date, however, worldwide experiments are relatively rare to enumerate capabilities of tied-ridge with biochar on sloped lands, in terms of their capacity to guarantee food security and dealing with extreme conditions, such as drought. This study reports the influence of tied-ridge with biochar amendment on soil temperature, moisture, runoff, sediment losses, and alfalfa fodder yield. The specific objectives of this study were (1) to determine whether biochar amendment in tied ridging reduces soil temperature, runoff, and sediment losses on sloping lands, and (2) to determine optimum mulch recommendation with tied ridging that will produce high alfalfa yield and water use efficiency in semiarid Loess Plateau of China. 
195

196

197

198

199

200

201

202

203

204

205

206

207

208

209

210

211

212

213

214

215

216

217

218

219

220

221

222

223

224

225

226

227

228

229

230

231

232

233

\section{Materials and methods}

\section{Schematic overview of the experimental program}

The schematic overview of the experimental program, from identification of the experimental station, to sampling and measurements of alfalfa cultivation in tied-ridge with biochar amendments, is displayed in Figure 1. For emphasis, the purpose of this research was to examine the influence of tied-ridge with biochar amendment on runoff, sediment losses, and alfalfa yield in northwestern China. The study implemented a completely randomized design with three replications. Tied-ridging, open-ridging, and flat planting were the three tillage systems used, at a $7^{\circ}$ slope. The biodegradable film (Ecoflex FS) used to mulch the ridges were $0.008 \mathrm{~mm}$ in thickness. Biochar applied in furrows was manufactured from maize straw at 400 ${ }^{\circ} \mathrm{C}$ through pyrolysis and thermal decomposition at Sanli New Energy Company in Henan, China, and applied at $30000 \mathrm{~kg} \mathrm{ha}^{-1}$ in the fields (Luo et al., 2017).

\section{The experimental station}

Field research was piloted at Anjiagou Catchment during alfalfa cultivation period from April-October (2020). The terrain of this area (latitude $35^{\circ} 34^{\prime} \mathrm{N}$, longitude $104^{\circ} 39^{\prime} \mathrm{E}$, and altitude $2075 \mathrm{~m}$ a.s.1.) is mountainous with steep slopes (converted to grasslands after 'Grain-forGreen Policy' enacted in the 1990s). The experimental station is situated 2-3 km east of Dingxi city, Gansu Province, Northwest China (Figure 2). The area is semi-arid with mean annual air temperature $\left(7.2^{\circ} \mathrm{C}\right)$ and monthly mean temperatures ranging from $1.1^{\circ} \mathrm{C}$ in January to $19.1^{\circ} \mathrm{C}$ in July. . The soil type on the experimental station is calcic cambisol, according to American soil classifications (Chen et al., 2013). The soil chemical properties are outlined in Table 1. The farming practice in this area is monoculture with once a year crop harvesting due to low temperatures. The main crops grown in this area are proso millet (Panicum miliaceum), spring wheat (Triticum aestivum), potato (Solanum tuberosum), maize (Zea mays), and flax (Linum usitatissimum). The major fodder grass species are sainfoin (Onobrychis viciifolia) and alfalfa (Medicago sativa).

\section{Experimental design}

In a completely randomized design, there were six plots ( 2 open / tied ridge with biodegradable film cover $\times 2$ biochar / no biochar +2 flat planting (FP) as control) with three replications. Tied-ridging, open-ridging, and flat planting were the three tillage systems used, at a $7^{\circ}$ slope. A ridge width, height, and furrow width of 45, 20, and $60 \mathrm{~cm}$ respectively, were used for open ridging and tied ridging. The ties in the tied ridging ranged from 10 to $15 \mathrm{~cm}$ in height and $20 \mathrm{~cm}$ in width (Figure 3). There was a $2.5 \mathrm{~m}$ distance between two non-staggered tiedridges. The biodegradable film (Ecoflex FS) used to mulch the ridges were $0.008 \mathrm{~mm}$ in thickness. The bio-degradable film was mass-produced by BASF Co Ltd, Germany. Biochar was manufactured from maize straw at $400{ }^{\circ} \mathrm{C}$ through pyrolysis and thermal decomposition at Sanli New Energy Company in Henan, China, and applied at $30000 \mathrm{~kg} \mathrm{ha}^{-1}$ in the fields (Luo et al., 2017). Biochar had a specific surface area of $44 \mathrm{~m}^{2} \mathrm{~g}^{-1}$, a bulk density of $0.45 \mathrm{~g} \mathrm{~cm}^{-3}, \mathrm{a} \mathrm{pH}(\mathrm{v} / \mathrm{v}$ 1:2.5 biochar: distilled water) of 7.5, a cation exchange capacity of $24.1 \mathrm{cmol} \mathrm{kg}^{-1}$, a water 
234 holding capacity $(24 \mathrm{~h})$ of $288 \%$, and Total C, and Total $\mathrm{N}$ content of 89 and $0.3 \%$, respectively. 235 In the exception of flat planting (control), experimental plots were $5.0 \mathrm{~m}$ wide and $10.05 \mathrm{~m}$ long, 236 with 9 ridges and 10 furrows (Figure 3). Each plot was surrounded by a $15 \mathrm{~cm}$ high panel to 237 accumulate runoff and sediment and to prevent runoff and sediment from adjacent plots. A gutter 238 was built at the bottom of each plot to channel runoff and sediment into a pool with a volume of $2392.25 \mathrm{~m}^{3}(1.5 \mathrm{~m}$ wide $\times 1.5 \mathrm{~m}$ long $\times 1.5 \mathrm{~m}$ deep $)$. There was a $1.5 \mathrm{~m}$ space between two plots. 240 Cement and bricks were used to build runoff and sediment collection pools to prevent 241 infiltration.

\section{Field management}

243 The fields were prepared when the soil was finally thawed on March 20, 2020, after clearing debris and litter. A 20 to $30 \mathrm{~cm}$ deep of high fertile soil was manually shoveled and piled up in accurate sizes and sloped with a tape measure and slope meter on April 2, 2020. Runoff, sediment collection pools, and boundaries were built on April 12, 2020. The furrows were used as planting zones after being ploughed, harrowed, and leveled. The bio-degradable film was laid on the ridges with edges buried 3 to $5 \mathrm{~cm}$ deep along ridge bases into the soil on April 12, 2020. Biochar was ground and screened through a 5-mm sieve before applied to the field. On April 15, 2020, before seeding alfalfa, biochar was broadcasted by hand and promptly ploughed into a 0-20 cm soil depth. Localized alfalfa (No 3 Gannong) cultivar was cultivated on April 15, 2020, at $22.5 \mathrm{~kg} \mathrm{ha}^{-1}$. Four rows were sown in a $60 \mathrm{~cm}$ wide furrow, 2-3 cm deep with $20 \mathrm{~cm}$ spaces between 2 rows (Figure 3). For tied ridging and open ridging, each experimental plot was $30 \mathrm{~m}^{2}$, with 10 furrows $(0.6 \mathrm{~m}$ width $\times 5 \mathrm{~m}$ length $)$ and 40 alfalfa planted rows. Flat planting plots were $50.25 \mathrm{~m}^{2}$ (5.0 width $\times 10.05 \mathrm{~m}$ length) with 66 alfalfa rows. Around 2 months after sowing, tied-ridges were manually built (June 14, 2020). Weeds were manually controlled with care to avoid breaking the ridges and no fertilizer or irrigation was carried out on experimental fields.

259

260

261

262

263

264

265

266

267

268

269

\section{Sampling and measurements}

\section{Rainfall, runoff, and sediment losses}

Data were collected as previously described in Wang et al., (2018). Rainfall was measured on the experiment field with an automatic weather station (WSSTD1, England). Sediment debris in gutter was swept and collected with a broom and shovel into runoff and sediment pool after every main rainfall event. Runoff in the pool was calculated by multiplying inner basal area of the pool to runoff depth. Pool runoff was stirred with a shovel for 5 to $10 \mathrm{~min}$ for uniform suspension of soil particles in the water. Sampling was done immediately with three $1000 \mathrm{~mL}$ measuring flasks, and samples were dried to clear and weighted to estimate sediment transport. Runoff and sediment pools were emptied and swept after sampling to provide space for the next runoff and sediment data sampling. 
304

305

306

307

308

\section{Soil moisture}

During alfalfa cultivation period, soil moisture was measured gravimetrically to a depth of $200 \mathrm{~cm}$, with an increment of $20 \mathrm{~cm}$ at furrow bottom in each plot, at 10 days intervals, without considering soil moisture, before sowing or green-up and after cutting. Three random soil samples from top, middle and bottom (up-slope, middle-slope, and down-slope) of each plot were collected. The soil water content was determined in addition to other standard measurements on experimental plots, $24 \mathrm{hrs}$ after every rainfall ( $>5 \mathrm{~mm})$.

Fodder yield

At the early flowering phase (between the first and 25\% of flower) and senescence, alfalfa was manually harvested (cut) three times in all plots in 2020. After cutting, harvested alfalfa was immediately weighed, and $1 \mathrm{~kg}$ of the samples was dried in an oven at $105^{\circ} \mathrm{C}$ for an hour and then at $75^{\circ} \mathrm{C}$ for 72 hours to measure alfalfa fodder yield. Alfalfa fodder yield was measured in 2 methods: (1) net fodder yield (NFY) in furrows (excludes tied-ridged areas); (2) actual fodder yield (AFY) in land areas of ridges and furrows (includes tied-ridge areas).

\section{Calculations of runoff and sediment parameters}

Runoff, sediment yield, and runoff efficiency were calculated using these formulae.

$$
\begin{aligned}
& V_{\text {runoff }}=A_{\text {pool }} \times D_{\text {pool }} \\
& W_{\text {sediment }}=V_{\text {runoff }} \times\left(W_{\text {sample sediment }} / V_{\text {sample }}\right) \\
& D_{\text {runoff }}=V_{\text {runoff } /} A_{\text {plot }} \\
& W_{\text {sediment per area }}=W_{\text {sediment }} / A_{\text {plot }} \\
& \mathrm{RE}=V_{\text {runoff }} /\left(P \times A_{\text {plot }}\right)
\end{aligned}
$$

where $V_{\text {runoff }}\left(\mathrm{m}^{3}\right)$ is pool runoff, $A_{\text {pool }}\left(2.25 \mathrm{~m}^{2}\right)$ is pool inner basal area, $D_{\text {pool }}(\mathrm{m})$ is pool runoff depth, $\mathrm{W}_{\text {sediment }}(\mathrm{g})$ is pool sediment weight, $\mathrm{V}_{\text {sample }}(\mathrm{L})$ is collected sample, $\mathrm{W}_{\text {sample sediment }}$ (g) is sample sediment weight, $D_{\text {runoff }}\left(\mathrm{Lm}^{-2}\right)$ is runoff depth, $A_{\text {plot }}\left(\mathrm{m}^{2}\right)$ is plot projection area, $\mathrm{W}_{\text {sediment }}$ per area $\left(\mathrm{gm}^{-2}\right)$ is sediment per area weight, RE $(\%)$ is runoff efficiency, and $\mathrm{P}(\mathrm{mm})$ is precipitation. The total actual evapotranspiration (ET, $\mathrm{mm}$ ) for alfalfa cultivation period and water use efficiency (WUE, $\mathrm{kg} \mathrm{ha}^{-1} \mathrm{~mm}^{-1}$ ) of alfalfa were calculated using these formulae ( $\mathrm{Li}$ and Gong, 2002):

$$
\mathrm{ET}=\mathrm{P}+\left(W_{1}-W_{2}\right)
$$

$$
\mathrm{WUE}=N F Y / E T
$$


where $\mathrm{P}$ is precipitation $(\mathrm{mm})$ during alfalfa cultivation period, NFY $\left(\mathrm{kg} \mathrm{ha}^{-1}\right)$ is net fodder yield, and AFY $\left(\mathrm{kg} \mathrm{ha}^{-1}\right)$ is actual fodder yield. The filtration and recharge from groundwater are negligible in this area (Zhao et al., 2012). Soil moisture $\left(\mathrm{W}_{1}\right.$ and $\mathrm{W}_{2}$ ) was also estimated with equation:

$\mathrm{W}=\underset{i=1}{10} \theta_{i} \times \rho d_{i} \times H \times 10$ $\left(\mathrm{g} \mathrm{cm}^{-3}\right)$.

Where $\theta$ is soil water content $(\%), \mathrm{H}$ is soil profile thickness $(\mathrm{cm}) ; \rho d$ is soil bulk density

Statistical analysis

An SPSS statistical software package (version 26.0, SPSS Inc., IL, Chicago, USA) was used to analyze all the data. Differences between treatments were analyzed using a one-way analysis of variance (ANOVA) followed by Tukey Pairwise comparison at 5\% significance and a linear regression analysis. The research location was mapped by GIS software (ESRI ${ }^{\circledR}$

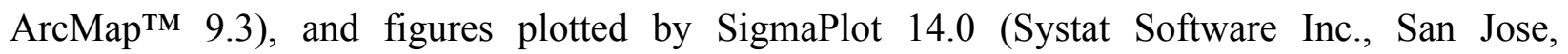
California, USA).

\section{Results}

Rainfall

Annual rainfall was $512.5 \mathrm{~mm}$, with $451.2 \mathrm{~mm}$ falling during the alfalfa cultivation season (April 1 to October 9, Figure 4). From January to December, monthly rainfall was 7.5, $4.7,13.4,15,75,80.5,91.2,138.2,44.8,28.2,10.2$, and $3.8 \mathrm{~mm}$, respectively. In the experimental year, rainfall from April to October accounted for 88 percent of total annual precipitation.

\section{Runoff, runoff efficiency, and sediment losses}

Runoff in flat planting (30\%), open ridging (45\%), and tied ridging (52\%) were decreased with biochar as sediment yield was decreased in flat planting (33\%), open ridging (43\%), and tied ridging (44\%) (Figure 5). Compared to flat planting, mean runoff was reduced in open ridging (38\%) and tied ridging (55\%) with biochar, and decreased in open ridging (20\%) and tied ridging (33\%) with no-biochar. Again, when compared to flat planting, sediment yield was considerably lower in open ridging $(70 \%)$ and tied ridging $(85 \%)$ with biochar, comparable to a drop in sediment production in open ridging $(65 \%)$ and tied ridging $(82 \%)$ with no-biochar. Runoff efficiency was decreased in open ridging (35\%) and tied ridging (52\%) with biochar amendment whereas runoff efficiency was decreased in open ridging $(19 \%)$ and tied ridging $(35 \%)$ with no-biochar compared to flat planting. Mean runoff efficiency was decreased in flat 
345

346

347

348

349

350

351

352

353

354

355

356

357

358

359

360

361

362

363

364

365

366

367

368

369

370

371

372

373

374

375

376

377

378

379

380

381

382

383

planting (31\%), open ridging (45\%), and tied ridging (50\%) with biochar amendments compared to no-biochar. Thus, decrease in runoff and sediment in open and tied ridging rainwater harvesting methods may be attributed to decrease in runoff efficiency, as demonstrated by this experiment.

\section{Soil temperature}

Mean soil temperatures on ridges and in furrows increased from April to July and then decreased until October during alfalfa growing season with biochar or no-biochar (Figure 6). Mean soil temperatures on ridges and furrows in biochar plots were higher than in no-biochar plots. Concurrently, mean soil temperatures in biochar and no-biochar plots ranged from $14{ }^{\circ} \mathrm{C}$ to $26{ }^{\circ} \mathrm{C}$. In furrows of biochar and no-biochar plots, mean soil temperatures varied from $12{ }^{\circ} \mathrm{C}$ to $23{ }^{\circ} \mathrm{C}$ and $12{ }^{\circ} \mathrm{C}$ to $24{ }^{\circ} \mathrm{C}$, respectively. During alfalfa cultivation period with biochar or nobiochar, soil temperature on ridges of tied ridging (TR) was significantly higher than that on open ridging (OR), which was significantly higher than that on flat planting (FP). Again, during alfalfa cultivation cycle with biochar, soil temperatures on ridges were significantly $(\mathrm{p}=0.00 ; \mathrm{F}$ $=0.05 ; \mathrm{R}$ square $=0.006 ;$ Adjusted R Square $=-0.105)$ increased in TR $(24 \%)$ and OR $(18 \%)$ relative to FP, and corresponding soil temperatures on ridges were increased in TR (20\%) and OR (14\%) in no-biochar plots. Meanwhile, during alfalfa cultivation period, soil temperature in furrows in biochar and no-biochar plots were in the order FP $>$ OR $>$ TR. Soil temperature was lower in TR (7\%) and OR (4\%) in biochar amended plots compared to FP, whereas in no-biochar plots, soil temperature was lower in TR (6\%) and OR (4\%). However, temperature differences in furrows with biochar amendment and in no-biochar plots were discovered to be non-significant $(\mathrm{p}=0.43 ; \mathrm{F}=0.86 ; \mathrm{R}$ square $=0.088$; Adjusted $\mathrm{R}$ Square $=-0.014)$ for TR, OR, and FP. According to findings from this study, decrease in soil temperature in tied ridging with biochar can be attributed to reduction in runoff and sediment.

\section{Soil water storage}

Monthly soil water storage increased in tied ridging compared to open ridging, which was also higher than flat planting in biochar plots from April to June (Figure 7). However, mean soil water storage increased in open ridging compared to tied ridging, which was higher than flat planting from July to October. The mean soil water storage was significantly higher in OR $(\mathrm{p}=$ $0.00)$ and TR $(p=0.01)$, as compared to FP in biochar amended plots $(\mathrm{F}=14.76$; $\mathrm{R}$ square $=$ 0.48 ; Adjusted R Square $=0.39)$. In no-biochar plots $(\mathrm{F}=10.97$; $\mathrm{R}$ square $=0.65$; Adjusted $\mathrm{R}$ Square $=0.59)$, mean soil water storage was significantly higher in OR $(\mathrm{p}=0.01)$ and $\mathrm{TR}(\mathrm{p}=$ 0.00 ), as compared to FP. During alfalfa cultivation period, mean soil water storage in middleslope was higher than in down-slope, which was higher than in up-slope. The mean soil water storage for flat planting, open ridging, and tied ridging with biochar amendments was 243, 302, and $292 \mathrm{~mm}$, respectively, while mean soil water storage for FP, OR, and TR with no-biochar was 232, 295, and $232 \mathrm{~mm}$. In comparison to no-biochar, biochar amendments resulted in significantly $(\mathrm{p}=0.0)$ higher mean soil water storage for FP, OR, and TR. This finding implies

that biochar amendments have a positive effect on soil water storage in open ridging compared to 
384

385

386

387

388

389

390

391

392

393

394

395

396

397

398

399

400

401

402

403

404

405

406

407

408

409

410

411

412

413

414

415

416

417

418

419

420

421

422

423

tied ridging. This could be attributed to lower runoff, sediment losses, and soil temperatures in the treatment fields.

Fodder yield and water use efficiency

With no-biochar, NFY of first cut in TR was higher compared to OR, while OR was also higher compared to FP (Table 2). However, for second and third cuts, NFY in OR was higher than TR, which was also higher than FP in no-biochar plots. Cumulative annual NFY of the treatments were in the order TR $>$ OR $>$ FP in no-biochar plots. In biochar plots, NFY was significantly $(\mathrm{p}=0.00 ; \mathrm{F}=98.767$; $\mathrm{R}$ square $=0.971$; Adjusted $\mathrm{R}$ Square $=0.961)$ higher among treatments in similar order as in no-biochar plots for first and second cuts. For third cut, NFY was in the order OR $>$ TR $>$ FP in biochar plots. Cumulative annual NFY increased in the order TR $>$ OR $>$ FP. The mean NFY was significantly higher $(p=0.04)$ in biochar amended plots than in no-biochar plots for all cuts. Consequently, TR had a significant effect on NFY in both biochar and no-biochar plots which could be due to increases in soil water storage in tied ridging.

Actual fodder yield was higher in TR which was higher than in OR which was higher than in FP for first cut with biochar amendments (Table 2). AFY was in the order OR $>$ TR $>$ FP in biochar plots for second and third cuts. Cumulative annual AFY with biochar amendments was significantly $(\mathrm{p}=0.02)$ higher in TR than in OR, which was in turn significantly $(\mathrm{p}<$ 0.0001) higher than in FP. Furthermore, in no-biochar plots, AFY for first and third cuts was in the order OR $>$ TR $>$ FP. Subsequently, AFY was higher in all treatments with OR recording highest AFY whiles FP recorded lowest for second cut in no-biochar plots. Twelve-monthly AFY in no-biochar plots for all treatments was in the order OR $>$ TR $>$ FP. The mean actual fodder yield was significantly $(\mathrm{p}=0.00 ; \mathrm{F}=937.6 ; \mathrm{R}$ square $=0.99$; Adjusted $\mathrm{R}$ Square $=0.996$ ) higher in biochar amended plots than in no-biochar plots for all cuts. As a result, tied ridging had a significant effect on actual fodder yield in biochar plots, while open ridging had a significant effect on actual fodder yield in no-biochar plots. As demonstrated by this research, this can be attributed to a reduction in runoff and sediment losses, which lead to an increase in soil water storage in treatment fields.

Water use efficiency (WUE) was highly significant ( $\mathrm{p}<0.0001 ; \mathrm{F}=1.460 ; \mathrm{R}$ square $=$ 0.378; Adjusted R Square $=0.119$ ) in tied ridging, compared to OR and FP in biochar and nobiochar plots (Table 2). Additionally, mean WUE was highly significant $(\mathrm{p}=0.01 ; \mathrm{F}=5.08 ; \mathrm{R}$ square $=0.62$; Adjusted $\mathrm{R}$ Square $=0.505$ ) in biochar plots than in no-biochar plots. Open ridging with biochar amendments increased net fodder yield (7.5\%) compared to open ridging in no-biochar plots, while tied ridging with biochar amendments increased net fodder yield $(8.5 \%)$ when compared to tied ridging in no-biochar plots. Open ridging with biochar amendments significantly $(\mathrm{p}<0.0001 ; \mathrm{F}=1187.047$; $\mathrm{R}$ square $=0.998$; Adjusted R Square $=0.997)$ increased actual fodder yield $(9.3 \%)$ compared to open ridging in no-biochar plots, while tied ridging with biochar amendments significantly $(\mathrm{p}=0.0001 ; \mathrm{F}=1187.047$; $\mathrm{R}$ square $=0.998$; Adjusted $\mathrm{R}$ Square $=0.997)$ increased actual fodder yield $(15.7 \%)$ compared to tied ridging in no-biochar plots. Biochar plots had a higher average annual mean net fodder yield (8\%) and actual fodder yield (11\%) than in no-biochar plots. The increase in WUE with biochar amendments in tied

PeerJ reviewing PDF | (2021:04:60167:2:0:CHECK 3 Jul 2021) 
424 ridging may be connected to the increase in yield and decrease in runoff and sediment, as 425 demonstrated by this experiment.

426

427

428

429

430

431

432

433

434

435

436

437

438

439

440

441

442

443

444

445

446

447

448

449

450

451

452

453

454

455

456

457

458

459

460

461

462

\section{Discussion}

Poor and erratic rainfall in semi-arid areas is a challenge to rain-fed agriculture, where farmers may experience crop damage (Graef \& Haigis, 2001). From this experiment, we found a decrease in runoff in flat planting (FP), open ridging (OR), and tied ridging (TR) by 30\%, 45\%, and $52 \%$, respectively, and corresponding sediment yield decrease of $33 \%, 43 \%$, and $44 \%$, respectively, with biochar amendments (Please, refer to Figure 5). When compared to no-biochar plots, mean runoff efficiency in flat planting, open ridging, and tied ridging was decreased by $31 \%, 45 \%$, and 50\%, respectively, with biochar amendments (Please, refer to Figure 5). These results are in line with those of Araya \& Stroosnijder (2010) who found runoff in tied ridges in a wheat field was significantly lower than runoff in a flat field. Nuti et al. (2009) elucidated that decreased runoff in tied ridges results in water storage in soil profiles which leads to improved crop development with higher crop yields. Furthermore, Patil \& Sheelavantar (2004) reported decreased runoff with compartmental bunding and ridges and furrows relative to flat planting. Concurrently, tied-ridges decreased runoff by 51 and 58\%, in Machanga, Kenya, during short and long rainy seasons, respectively (Okeyo et al., 2014). In a similar research in Upper Volta, tied ridges resulted in $0.9 \%$ runoff relative to $6.3 \%$ with open ridges and $12.2 \%$ in flat planting (Gerbu, 2015). Xia et al. (2014) came to a similar conclusion, finding a substantial reduction in runoff, phosphorus, and nitrogen losses. According to Woldegiorgis (2017), effectiveness of tied ridging to decrease soil erosion was predominantly connected to decrease in runoff in tied ridge fields.

From this research, in biochar and no-biochar fields, we found soil temperatures on ridges of TR were significantly higher than on OR, which was significantly higher than on FP during alfalfa cultivation period. Conversely, soil temperature in furrows during alfalfa cultivation period in biochar and no-biochar fields were significantly higher in treatments in the order FP $>$ OR $>$ TR (Please, refer to Figure 6). This finding is in agreement with Genesio et al. (2012), who discovered dark-colored biochar increased soil temperatures compared to nobiochar. This may be attested to decrease in runoff and sediment with biochar amendment in this experiment.

Implementation of soil moisture preservation practices such as tied ridges with mulching has presented improved soil moisture retention in different environments (Ndlangamandla et al., 2016). In comparison to no-biochar, mean soil water storage was found to be significantly higher in FP, OR, and TR with biochar (Please, refer to Figure 7). This demonstrates the positive influence of biochar amendments in tied ridging on soil water storage. This result is in line with Ndlangamandla et al. (2016), who found that soil moisture in the tied ridges with mulch was retained longer than in un-mulched ridges. These outcomes are also in agreement with Mupangwa et al. (2006) and Nyamadzawo et al. (2013), who revealed tied ridges, are effective at trapping and concentrating moisture in the root zone of plants. Adimassu et al. (2014) and Al- 
463 Seekh \& Mohammad (2009) also reported lower runoff and higher soil moisture content. In 464 similar research by McHugh et al. (2007), open ridges performed second best with higher 465 seasonal soil moisture than subsoiling, no-till, and traditional tillage. Again, Araya \& 466 Stroosnijder (2010) reported tied ridging with mulching can increase soil water in the root zone 467 of plants by $13 \%$ and crop grain yield (barley) by $44 \%$ during below-average rainfall years. 468 Conversely, tied ridging with soil bund and tied ridging with mulch increased soil water storage by $5.37 \%$ and $6.20 \%$, respectively, compared to flat planting (Adeboye et al., 2017).

In this study, annual cumulative net fodder yield (NFY) was significantly higher in TR, which was significantly higher compared to OR, which too was significantly higher compared to FP (Please, refer to Table 2). This is in line with Zelelew et al., (2018), whose findings indicated that plots treated with tied ridge had the highest grain yield $\left(2302 \mathrm{~kg} \mathrm{ha}^{-1}\right)$ and biomass $(7647 \mathrm{~kg}$ $\left.\mathrm{ha}^{-1}\right)$. Grain yield for tied ridges with mulch was substantially different $(\mathrm{p}<0.05)$ from bare tied ridges and flat planting, according to Ndlangamandla et al. (2016). The significant difference among these treatments is agreed to be as a result of moisture retention which was attained as an effect of mulching (Ndlangamandla et al., 2016). In another study, pearl millet yield was significantly increased in tied ridging than in flat planting (Silungwe et al., 2019). Tied ridging has been successful in other semi-arid areas for cereals like sorghum (Sorghum bicolor) (Mesfin et al., 2009; Bayu et al., 2012). The yield of crops (sorghum, maize, wheat, and mung bean) grown with tied ridging significantly increased (50 to 100\%) as compared to flat planting in semi-arid areas (Zelelew et al., 2018). Correspondingly, relative to flat planting, furrow planting in open-end tied ridges resulted in a $28.86 \%$ increase in stover yield (Belachew \& Abera, 2014). The grain yield harvested in tied ridging $\left(3.6 \mathrm{tha}^{-1}\right)$ was higher $(12.5 \%)$ compared to flat planting (3.2 $\mathrm{t} \mathrm{ha}^{-1}$ ) (Yoseph, 2014). Furthermore, maize biomass yield (11019 $\left.\mathrm{kg} \mathrm{ha}^{-1}\right)$ in closed-end tied ridging was highest with a 54.9\% increase compared to flat planting (Belachew \& Abera, 2014). In addition, Sumeriya et al. (2014) revealed an increase in sorghum grain yield ranging from 67 to $73 \%$ and soil water $(40 \%)$ in tied ridging compared to flat planting. As a consequence, depending on rainfall and slope gradient, tied ridging has been shown to increase yields (Motsi et al., 2004; McHugh et al., 2007).

With biochar amendments, tied ridging had a significant effect on actual fodder yield (AFY), while OR had a significant effect on AFY with no biochar. Biochar improved the annual cumulative mean of NFY (8\%) and AFY (11\%) as compared to no-biochar in this study (Please, refer to Table 2). These outcomes are in line with Mak-Mensah et al. (2021), who reported combined application of biodegradable film with biochar in the Loess Plateau of China increased yield by $22.86 \%$ compared with FP. This was corroborated by Liu et al. (2014) who achieved a higher yield of sweet potato $(53.77 \% ; \mathrm{p}<0.05)$, with biochar amendment than with no biochar treatment (control). In addition, Liang et al. (2014) obtained a 10\% increase in grain yield in winter wheat and summer maize with biochar application compared to controls (no biochar). Furthermore, Xiao et al., (2016) found that 20 and $30 \mathrm{t} \mathrm{ha}^{-1}$ biochar amendment improved wheat yields by 9 and 13\% in 2012 and 11 and 14\% in 2013, respectively, compared to no biochar treatments. In comparing biodegradable film mulched ridge-furrow with $20 \mathrm{t} \mathrm{ha}^{-1}$ biochar 
503

504

505

506

507

508

509

510

511

512

513

514

515

516

517

518

519

520

521

522

523

524

525

526

527

528

529

530

531

532

533

534

535

536

537

538

539

540

541

application to biodegradable film mulched ridge-furrow without biochar treatments, wheat grain yield increased by 6 and 9\% in 2012 and 2013 (Xiao et al., 2016). In addition, a meta-analysis by Jeffery et al. (2011) found that biochar-treated soils enhanced crop productivity by $10 \%$ on average when compared to plots without mulching. Under co-application of biodegradable film mulched ridge-furrow with biochar treatment, the residual impact of biochar on soil fertility accounted for the majority of improvement in crop production (Rehman \& Razzaq, 2017).

Improving water use efficiency in semi-arid regions can be attained either by increasing the volume of water accessible to plants for transpiration and/or by increasing efficacy with which transpired water yields more plant biomass (Wallace, 2000). Water use efficiency was in the order TR $>$ OR $>$ FP with no-biochar or biochar amendments (Please, refer to Table 2). The mean WUE was significantly higher in biochar plots than in non-biochar plots in this present research. These outcomes are consistent with Ndlangamandla et al. (2016) who reported increased soil moisture and crop yield with mulching in tied-ridging in Swaziland's semiarid areas. This may be an ideal agronomic practice for smallholder farmers to increase yield in crop production. The practice could also be used as a soil and water conservation strategy in rain-fed agriculture, especially in climate-changing areas to reduce drought impact while decreasing runoff and erosion (Mak-Mensah et al., 2021).

\section{Conclusions}

The tied ridge with biochar amendments in alfalfa cultivation has been shown to reduce runoff and significantly improve rainfall infiltration into the soil. Field investigation revealed biochar amendments reduced runoff in flat planting, open ridging, and tied ridging, resulting in a decrease in sediment yield. Mean runoff efficiency was decreased in flat planting, open ridging, and tied ridging, with biochar amendments compared to no-biochar. During the alfalfa cultivation period with biochar or no-biochar, soil temperature on tied ridging ridges was significantly higher than that on open ridging, which was significantly higher than flat planting. In comparison to no-biochar, mean soil water storage for flat planting, open ridging, and tied ridging with biochar was significantly higher. This signifies the viability of biochar amendment in improving soil water storage in open ridging. Biochar increased annual cumulative net fodder yield and actual fodder yield means compared to no-biochar. Conversely, mean water use efficiency with biochar amendment was significantly higher than in no-biochar. Thus, when crop production is threatened by soil erosion and drought, tied ridging with biochar is beneficial to crop growth in rain-fed agriculture.

The study's main constraints were labor costs for creating ties, filming, and applying biochar, all of which are time-consuming tasks that need manual work. Other constraints discovered during this investigation include limited access to farm inputs, and the high cost of biochar and biodegradable film, low soil fertility and lack of fertilizer application. Thus, there is a great need to examine nutrient loss reductions of alfalfa cultivation under a wide range of growing conditions and locations. Further research is needed on better plant water uptake cultivars or species, strategies for minimizing unproductive water losses, and consistent rodents 
542

543

544

545

546

547

548

549

550

551

552

553

554

555

556

557

558

559

560

561

562

563

564

565

566

567

568

569

570

571

572

573

574

575

576

577

578

579

580

and weeds control. In addition, the economic viability of alfalfa cultivation in tied-ridges with biochar amendments needs to be evaluated in response to drastic increases in input costs. Although, smallholder farmers in semi-arid areas could be trained in the use of this water-saving technique to reduce runoff, soil erosion, sediment losses, and improve food security, to overcome cultural and sociological reluctance in both rural and urban communities to deploy and accept this system, new ways for disseminating knowledge about tied-ridges with biochar amendments are needed.

\section{References}

Abrantes JRCB, Prats SA, Keizer JJ, de Lima JLMP. 2018. Effectiveness of the application of rice straw mulching strips in reducing runoff and soil loss: Laboratory soil flume experiments under simulated rainfall. Soil and Tillage Research 180:238-249. DOI: 10.1016/j.still.2018.03.015.

Adeboye OB, Schultz B, Adekalu KO, Prasad K. 2017. Soil water storage, yield, water productivity, and transpiration efficiency of soybeans ( Glyxine max L.Merr) as affected by soil surface management in Ile-Ife, Nigeria. International Soil and Water Conservation Research 5:141-150. DOI: 10.1016/j.iswcr.2017.04.006.

Ademe D, Bekele B, Gebremichael A. 2018. On-farm Verification of the Soil Moisture and Yield Response of Tied Ridge on Maize Production in Dry Areas of SNNPR, Ethiopia. Journal of Environment and Earth Science ISSN 8.

Adimassu Z, Mekonnen K, Yirga C, Kessler A. 2014. Effect of soil bunds on runoff, soil and nutrient losses, and crop yield in the central highlands of Ethiopia. Land Degradation and Development 25:554-564. DOI: 10.1002/1dr.2182.

Al-Seekh SH, Mohammad AG. 2009. The Effect of Water Harvesting Techniques on Runoff, Sedimentation, and Soil Properties. Environmental Management 44:37-45. DOI: 10.1007/s00267-009-9310-z.

Anyanwu IN, Alo MN, Onyekwere AM, Crosse JD, Nworie O, Chamba EB. 2018. Influence of biochar aged in acidic soil on ecosystem engineers and two tropical agricultural plants. Ecotoxicology and Environmental Safety 153:116-126. DOI: 10.1016/j.ecoenv.2018.02.005.

Araya A, Stroosnijder L. 2010. Effects of tied ridges and mulch on barley (Hordeum vulgare) rainwater use efficiency and production in Northern Ethiopia. Agricultural Water Management 97:841-847. DOI: 10.1016/j.agwat.2010.01.012.

Bado BV, Whitbread A, Sanoussi Manzo ML. 2021. Improving agricultural productivity using agroforestry systems: Performance of millet, cowpea, and ziziphus-based cropping systems in West Africa Sahel. Agriculture, Ecosystems \& Environment 305:107175. DOI: 10.1016/j.agee.2020.107175.

Bajgai Y, Hulugalle N, Kristiansen P, McHenry M, Cowie A. 2014. Residue incorporation mitigates tillage-induced loss of soil carbon in laboratory microcosms. Soil Use and Management 30:328-336. DOI: 10.1111/sum.12130. 
581

582

583

584

585

586

587

588

589

590

591

592

593

594

595

596

597

598

599

600

601

602

603

604

605

606

607

608

609

610

611

612

613

614

615

616

617

618

619

620

Bayu W, Rethman NFG, Hammes PS. 2012. Effects of tied-ridge, nitrogen fertilizer, and cultivar on the yield and nitrogen use efficiency of sorghum in semi-arid Ethiopia. Archives of Agronomy and Soil Science 58:547-560. DOI: 10.1080/03650340.2010.532488.

Belachew T, Abera Y. 2014. Response of maize ( Zea mays L .) to tied ridges and planting methods at Goro, Southeastern Ethiopia. American-Eurasian Journal of Agronomy 3(1):2124.

Bennie ATP, Hensley M. 2001. Maximizing precipitation utilization in dryland agriculture in South Africa - A review. Journal of Hydrology 241:124-139. DOI: 10.1016/S00221694(00)00377-2.

Beshir S, Abdulkerim J. 2017. Effect of Maize/Haricot Bean Intercropping on Soil Fertility Improvement under Different Tied Ridges and Planting Methods, Southeast Ethiopia. Journal of Geoscience and Environment Protection 05:63-70. DOI: 10.4236/gep.2017.58007.

Biazin B, Stroosnijder L. 2012. To tie or not to tie ridges for water conservation in Rift Valley drylands of Ethiopia. Soil and Tillage Research 124:83-94. DOI: 10.1016/j.still.2012.05.006.

Brhane G, Wortmann CS, Mamo M, Gebrekidan H, Belay A. 2006. Micro-basin tillage for grain sorghum production in semiarid areas of Northern Ethiopia. Agronomy Journal 98:124-128. DOI: 10.2134/agronj2005-0148.

Bu L, Zhu L, Liu J, Luo S, Chen X, Li S. 2013. Source-Sink Capacity Responsible for Higher Maize Yield with Removal of Plastic Film. Agronomy Journal 105:591-598. DOI: 10.2134/agronj2012.0459.

Burrell LD, Zehetner F, Rampazzo N, Wimmer B, Soja G. 2016. Long-term effects of biochar on soil physical properties. Geoderma 282:96-102. DOI: 10.1016/j.geoderma.2016.07.019.

Chakraborty D, Nagarajan S, Aggarwal P, Gupta VK, Tomar RK, Garg RN, Sahoo RN, Sarkar A, Chopra UK, Sarma KSS, Kalra N. 2008. Effect of mulching on soil and plant water status, and the growth and yield of wheat (Triticum aestivum L.) in a semi-arid environment. Agricultural Water Management 95:1323-1334. DOI: 10.1016/j.agwat.2008.06.001.

Chen Y, Liu T, Tian X, Wang X, Li M, Wang S, Wang Z. 2015. Effects of plastic film combined with straw mulch on grain yield and water use efficiency of winter wheat in Loess Plateau. Field Crops Research 172:53-58. DOI: 10.1016/j.fcr.2014.11.016.

Chen Y, Wu J, Wang H, Ma J, Su C, Wang K, Wang Y. 2019. Evaluating the soil quality of newly created farmland in the hilly and gully region on the Loess Plateau, China. Journal of Geographical Sciences 29:791-802. DOI: 10.1007/s11442-019-1628-8.

Chen L, Yang L, Wei W. 2013. Towards Sustainable Integrated Watershed Ecosystem Management: A Case Study in Dingxi on the Loess Plateau, China. :126-137. DOI: 10.1007/s00267-011-9807-0.

Crane-Droesch A, Abiven S, Jeffery S, Torn MS. 2013. Heterogeneous global crop yield response to biochar: A meta-regression analysis. Environmental Research Letters 8. DOI:

PeerJ reviewing PDF | (2021:04:60167:2:0:CHECK 3 Jul 2021) 
10.1088/1748-9326/8/4/044049.

Denyes MJ, Rutter A, Zeeb BA. 2016. Bioavailability assessments following biochar and activated carbon amendment in DDT-contaminated soil. Chemosphere 144:1428-1434. DOI: 10.1016/j.chemosphere.2015.10.029.

Ding D, Zhao Y, Feng H, Hill RL, Chu X, Zhang T, He J. 2018. Soil water utilization with plastic mulching for a winter wheat-summer maize rotation system on the Loess Plateau of China. Agricultural Water Management 201:246-257. DOI: 10.1016/j.agwat.2017.12.029.

Donjadee S, Tingsanchali T. 2016. Soil and water conservation on steep slopes by mulching using rice straw and vetiver grass clippings. Agriculture and Natural Resources 50:75-79. DOI: 10.1016/j.anres.2015.03.001.

Du L, Wang R, Gao X, Hu Y, Guo S. 2020. Divergent responses of soil bacterial communities in erosion-deposition plots on the Loess Plateau. Geoderma 358:113995. DOI: 10.1016/j.geoderma.2019.113995.

Edeh IG, Mašek O, Buss W. 2020. A meta-analysis on biochar's effects on soil water properties - New insights and future research challenges. Science of The Total Environment 714:136857. DOI: 10.1016/j.scitotenv.2020.136857.

Fan J, Wang Q, Jones SB, Shao M. 2016. Soil water depletion and recharge under different land cover in China's Loess Plateau. Ecohydrology 9:396-406. DOI: 10.1002/eco.1642.

Fernández C, Vega JA, Jiménez E, Vieira DCS, Merino A, Ferreiro A, Fonturbel T. 2012. Seeding and mulching+seeding effects on post-fire runoff, soil erosion, and species diversity in Galicia (NW Spain). Land Degradation and Development 23:150-156. DOI: 10.1002/ldr.1064.

Fischer BMC, Manzoni S, Morillas L, Garcia M, Johnson MS, Lyon SW. 2019. Improving agricultural water use efficiency with biochar - A synthesis of biochar effects on water storage and fluxes across scales. Science of the Total Environment 657:853-862. DOI: 10.1016/j.scitotenv.2018.11.312.

Fu BJ, Meng QH, Qiu Y, Zhao WW, Zhang QJ, Davidson DA. 2004. Effects of land use on soil erosion and nitrogen loss in the hilly area of the Loess Plateau, China. Land Degradation and Development 15:87-96. DOI: 10.1002/1dr.572.

Gan Y, Siddique KHM, Turner NC, Li X-G, Niu J-Y, Yang C, Liu L, Chai Q. 2013. RidgeFurrow Mulching Systems-An Innovative Technique for Boosting Crop Productivity in Semiarid Rain-Fed Environments. In: Advances in Agronomy. Elsevier, 429-476. DOI: 10.1016/B978-0-12-405942-9.00007-4.

Genesio L, Miglietta F, Lugato E, Baronti S, Pieri M, Vaccari FP. 2012. Surface albedo following biochar application in durum wheat. Environmental Research Letters 7:014025. DOI: $10.1088 / 1748-9326 / 7 / 1 / 014025$.

Gerbu LH. 2015. On-Farm Evaluation of Sorghum ( Sorghum bicolor L . Moench ) Varieties Under Tie Ridge and NP Fertilizer at Mekeredi, Moisture Stress Area of Amaro, Southern Ethiopia. Agricultural and Biological Sciences Journal 1:37-41.

Głąb T, Palmowska J, Zaleski T, Gondek K. 2016. Effect of biochar application on soil 
661

662

663

664

665

666

667

668

669

670

671

672

673

674

675

676

677

678

679

680

681

682

683

684

685

686

687

688

689

690

691

692

693

694

695

696

697

698

699

700

hydrological properties and physical quality of sandy soil. Geoderma 281:11-20. DOI: 10.1016/j.geoderma.2016.06.028.

Glaser B, Birk JJ. 2012. State of the scientific knowledge on properties and genesis of Anthropogenic Dark Earths in Central Amazonia (terra preta de Índio). Geochimica et Cosmochimica Acta 82:39-51. DOI: 10.1016/j.gca.2010.11.029.

Gonzaga MIS, Mackowiak C, de Almeida AQ, de Carvalho Junior JIT, Andrade KR. 2018. Positive and negative effects of biochar from coconut husks, orange bagasse and pine wood chips on maize (Zea mays L.) growth and nutrition. Catena 162:414-420. DOI: 10.1016/j.catena.2017.10.018.

Graef F, Haigis J. 2001. Spatial and temporal rainfall variability in the Sahel and its effects on farmers' management strategies. :221-231. DOI: 10.1006/jare.2000.0747.

Guzha AC. 2004. Effects of tillage on soil microrelief, surface depression storage and soil water storage. Soil and Tillage Research 76:105-114. DOI: 10.1016/j.still.2003.09.002.

Han J, Jia Z, Han Q, Zhang J. 2013. Application of Mulching Materials of Rainfall Harvesting System for Improving Soil Water and Corn Growth in Northwest of China. Journal of Integrative Agriculture 12:1712-1721. DOI: 10.1016/S2095-3119(13)60342-1.

Han F, Ren L, Zhang XC. 2016. Effect of biochar on the soil nutrients about different grasslands in the Loess Plateau. Catena 137:554-562. DOI: 10.1016/j.catena.2015.11.002.

Hardie M, Clothier B, Bound S, Oliver G, Close D. 2014. Does biochar influence soil physical properties and soil water availability? Plant and Soil 376:347-361. DOI: 10.1007/s11104013-1980-x.

Hol WHG, Vestergård M, ten Hooven F, Duyts H, van de Voorde TFJ, Bezemer TM. 2017. Transient negative biochar effects on plant growth are strongest after microbial species loss. Soil Biology and Biochemistry 115:442-451. DOI: 10.1016/j.soilbio.2017.09.016.

Howell TA, Schneider AD, Dusek DA. 2000. Effects of furrow diking on corn response to limited and full sprinkler irrigation. 2000 ASAE Annual International Meeting, Technical Papers: Engineering Solutions for a New Century 2:1719-1738. DOI: 10.2136/sssaj2002.2220.

Jeffery S, Abalos D, Prodana M, Bastos AC, Van Groenigen JW, Hungate BA, Verheijen F. 2017. Biochar boosts tropical but not temperate crop yields. Environmental Research Letters 12. DOI: 10.1088/1748-9326/aa67bd.

Jeffery S, Verheijen FGA, van der Velde M, Bastos AC. 2011. A quantitative review of the effects of biochar application to soils on crop productivity using meta-analysis. Agriculture, Ecosystems and Environment 144:175-187. DOI: 10.1016/j.agee.2011.08.015.

Jensen J., Bernhard R., Hansen S, McDonagh J, Møberg J., Nielsen N., Nordbo E. 2003. Productivity in maize-based cropping systems under various soil-water-nutrient management strategies in a semi-arid, alfisol environment in East Africa. Agricultural Water Management 59:217-237. DOI: 10.1016/S0378-3774(02)00151-8.

Jia Q, Sun L, Mou H, Ali S, Liu D, Zhang Y, Zhang P, Ren X, Jia Z. 2018. Effects of planting patterns and sowing densities on grain-filling, radiation use efficiency, and yield of maize 
701

702

703

704

705

706

707

708

709

710

711

712

713

714

715

716

717

718

719

720

721

722

723

724

725

726

727

728

729

730

731

732

733

734

735

736

737

738

739

740

(Zea mays L.) in semi-arid regions. Agricultural Water Management 201:287-298. DOI: 10.1016/j.agwat.2017.11.025.

Jiménez MN, Fernández-Ondoño E, Ripoll MÁ, Castro-Rodríguez J, Huntsinger L, Navarro FB. 2016. Stones and Organic Mulches Improve the Quercus Ilex L. Afforestation Success Under Mediterranean Climatic Conditions. Land Degradation and Development 27:357365. DOI: $10.1002 / 1 \mathrm{dr} .2250$.

Jin K, Cornelis WM, Schiettecatte W, Lu J, Yao Y, Wu H, Gabriels D, De Neve S, Cai D, Jin J, Hartmann R. 2007. Effects of different management practices on the soil-water balance and crop yield for improved dryland farming in the Chinese Loess Plateau. Soil and Tillage Research 96:131-144. DOI: 10.1016/j.still.2007.05.002.

Jones DL, Quilliam RS. 2014. Metal contaminated biochar and wood ash negatively affect plant growth and soil quality after land application. Journal of Hazardous Materials 276:362-370. DOI: 10.1016/j.jhazmat.2014.05.053.

Jordán A, Zavala LM, Gil J. 2010. Effects of mulching on soil physical properties and runoff under semi-arid conditions in southern Spain. Catena 81:77-85. DOI: 10.1016/j.catena.2010.01.007.

Joseph S, Kammann CI, Shepherd JG, Conte P, Schmidt HP, Hagemann N, Rich AM, Marjo CE, Allen J, Munroe P, Mitchell DRG, Donne S, Spokas K, Graber ER. 2018. Microstructural and associated chemical changes during the composting of a high temperature biochar: Mechanisms for nitrate, phosphate and other nutrient retention and release. Science of the Total Environment 618:1210-1223. DOI: 10.1016/j.scitotenv.2017.09.200.

Jun F, Mingan S, QuanJiu W, Jones SB, Reichardt K, Xiangrong C, Xiaoli F. 2010. Toward sustainable soil and water resources use in China's highly erodible semi-arid loess plateau. Geoderma 155:93-100. DOI: 10.1016/j.geoderma.2009.11.027.

Kammann C, Ratering S, Eckhard C, Müller C. 2012. Biochar and Hydrochar Effects on Greenhouse Gas (Carbon Dioxide, Nitrous Oxide, and Methane) Fluxes from Soils. Journal of Environmental Quality 41:1052-1066. DOI: 10.2134/jeq2011.0132.

Kim HS, Kim KR, Kim HJ, Yoon JH, Yang JE, Ok YS, Owens G, Kim KH. 2015. Effect of biochar on heavy metal immobilization and uptake by lettuce (Lactuca sativa L.) in agricultural soil. Environmental Earth Sciences 74:1249-1259. DOI: 10.1007/s12665-0154116-1.

Kirkham MB. 2014. Water Movement in Saturated Soil. Principles of Soil and Plant Water Relations:87-101. DOI: 10.1016/b978-0-12-420022-7.00007-0.

Kuzyakov Y, Bogomolova I, Glaser B. 2014. Biochar stability in soil: Decomposition during eight years and transformation as assessed by compound-specific 14C analysis. Soil Biology and Biochemistry 70:229-236. DOI: 10.1016/j.soilbio.2013.12.021.

Laird DA, Fleming P, Davis DD, Horton R, Wang B, Karlen DL. 2010. Impact of biochar amendments on the quality of a typical Midwestern agricultural soil. Geoderma 158:443449. DOI: 10.1016/j.geoderma.2010.05.013.

Lee G, McLaughlin RA, Whitely KD, Brown VK. 2018. Evaluation of seven mulch treatments 
741

742

743

744

745

746

747

748

749

750

751

752

753

754

755

756

757

758

759

760

761

762

763

764

765

766

767

768

769

770

771

772

773

774

775

776

777

778

779

780

for erosion control and vegetation establishment on steep slopes. Journal of Soil and Water Conservation 73:434-442. DOI: 10.2489/jswc.73.4.434.

Lehmann J, Rondon M. 2006. Bio-Char Soil Management on Highly Weathered Soils in the Humid Tropics. :517-529. DOI: 10.1201/9781420017113.ch36.

Lehmann J, Skjemstad J, Sohi S, Carter J, Barson M, Falloon P, Coleman K, Woodbury P, Krull E. 2008. Australian climate-carbon cycle feedback reduced by soil black carbon. Nature Geoscience 1:832-835. DOI: 10.1038/ngeo358.

Li R, Li Q, Pan L. 2020. Review of organic mulching effects on soil and water loss. Archives of Agronomy and Soil Science 00:1-16. DOI: 10.1080/03650340.2020.1718111.

Li C, Wen X, Wan X, Liu Y, Han J, Liao Y, Wu W. 2016. Towards the highly effective use of precipitation by ridge-furrow with plastic film mulching instead of relying on irrigation resources in a dry semi-humid area. Field Crops Research 188:62-73. DOI: 10.1016/j.fcr.2016.01.013.

Li S, Zhang Y, Yan W, Shangguan Z. 2018. Effect of biochar application method on nitrogen leaching and hydraulic conductivity in a silty clay soil. Soil and Tillage Research 183:100108. DOI: $10.1016 /$ j.still.2018.06.006.

Li Y, Zhang F, Yang M, Zhang J, Xie Y. 2019. Impacts of biochar application rates and particle sizes on runoff and soil loss in small cultivated loess plots under simulated rainfall. Science of The Total Environment 649:1403-1413. DOI: 10.1016/j.scitotenv.2018.08.415.

Liang F, Li G tong, Lin Q mei, Zhao X rong. 2014. Crop yield and soil properties in the first 3 years after biochar application to a calcareous soil. Journal of Integrative Agriculture 13:525-532. DOI: 10.1016/S2095-3119(13)60708-X.

Liang S min, Ren C, Wang P jun, Wang X ting, Li Y shan, Xu F hai, Wang Y, Dai Y qiong, Zhang L, Li X ping, Zhan K, Yang Q fen, Sui Q jun. 2018. Improvements of emergence and tuber yield of potato in a seasonal spring arid region using plastic film mulching only on the ridge. Field Crops Research 223:57-65. DOI: 10.1016/j.fcr.2018.03.012.

Lim TJ, Spokas KA, Feyereisen G, Novak JM. 2016. Predicting the impact of biochar additions on soil hydraulic properties. Chemosphere 142:136-144. DOI: 10.1016/j.chemosphere.2015.06.069.

Liu XH, Han FP, Zhang XC. 2012. Effect of biochar on soil aggregates in the Loess Plateau: Results from incubation experiments. International Journal of Agriculture and Biology 14:975-979.

Liu P, Wang H, Li L, Liu X, Qian R, Wang J, Yan X, Cai T, Zhang P, Jia Z, Ren X, Chen X. 2020. Ridge-furrow mulching system regulates hydrothermal conditions to promote maize yield and efficient water use in rainfed farming area. Agricultural Water Management 232:106041. DOI: 10.1016/j.agwat.2020.106041.

Liu Z, Chen X, Jing Y, Li Q, Zhang J, Huang Q. 2014. Effects of biochar amendment on rapeseed and sweet potato yields and water stable aggregate in upland red soil. Catena 123:45-51. DOI: 10.1016/j.catena.2014.07.005.

Lu J. 2015. Identification of Forensic Information from Existing Conventional Site-Investigation 
781

Data. In: Introduction to Environmental Forensics. Elsevier, 149-164. DOI: 10.1016/B9780-12-404696-2.00006-0.

Luo S, Wang S, Tian L, Li S, Li X, Shen Y, Tian C. 2017. Long-term biochar application influences soil microbial community and its potential roles in semiarid farmland. Applied Soil Ecology 117-118:10-15. DOI: 10.1016/j.apsoil.2017.04.024.

Mak-Mensah E, Obour PB, Essel E, Wang Q, Ahiakpa JK. 2021. Influence of plastic film mulch with biochar application on crop yield, evapotranspiration, and water use efficiency in northern China: A meta-analysis. PeerJ 9:e10967. DOI: 10.7717/peerj.10967.

Mandumbu R, Nyawenze C, Rugare JT, Nyamadzawo G, Parwada C, Tibugari H. 2020. Tied Ridges and Better Cotton Breeds for Climate Change Adaptation. In: African Handbook of Climate Change Adaptation. Cham: Springer International Publishing, 1-15. DOI: 10.1007/978-3-030-42091-8_23-1.

Martinsen V, Mulder J, Shitumbanuma V, Sparrevik M, Børresen T, Cornelissen G. 2014. Farmer-led maize biochar trials: Effect on crop yield and soil nutrients under conservation farming. Journal of Plant Nutrition and Soil Science 177:681-695. DOI: 10.1002/jpln.201300590.

Mason SC, Ouattara K, Taonda SJ-B, Palé S, Sohoro A, Kaboré D. 2015. Soil and cropping system research in semi-arid West Africa as related to the potential for conservation agriculture. International Journal of Agricultural Sustainability 13:120-134. DOI: 10.1080/14735903.2014.945319.

McHugh O V., Steenhuis TS, Berihun Abebe, Fernandes ECM. 2007b. Performance of in situ rainwater conservation tillage techniques on dry spell mitigation and erosion control in the drought-prone North Wello zone of the Ethiopian highlands. Soil and Tillage Research 97:19-36. DOI: 10.1016/j.still.2007.08.002.

Meng Q, Fu B, Tang X, Ren H. 2008. Effects of land use on phosphorus loss in the hilly area of the Loess Plateau, China. Environmental Monitoring and Assessment 139:195-204. DOI: 10.1007/s10661-007-9826-8.

Meng X, Lian Y, Liu Q, Zhang P, Jia Z, Han Q. 2020. Optimizing the planting density under the ridge and furrow rainwater harvesting system to improve crop water productivity for foxtail millet in semiarid areas. Agricultural Water Management 238:106220. DOI: 10.1016/j.agwat.2020.106220.

Mesfin T, Tesfahunegn GB, Wortmann CS, Nikus O, Mamo M. 2009. Tied-ridging and fertilizer use for sorghum production in semi-arid Ethiopia. Nutrient Cycling in Agroecosystems 85:87-94. DOI: 10.1007/s10705-009-9250-2.

Mo F, Wang J, Zhou H, Luo C, Zhang X, Li X-Y, Li F, Xiong L-B, Kavagi L, Nguluu SN, Xiong Y. 2017. Ridge-furrow plastic-mulching with balanced fertilization in rainfed maize ( Zea mays L.): An adaptive management in east African Plateau. Agricultural and Forest Meteorology 236:100-112. DOI: 10.1016/j.agrformet.2017.01.014.

Motsi KE, Chuma E, Mukamuri BB. 2004. Rainwater harvesting for sustainable agriculture in communal lands of Zimbabwe. Physics and Chemistry of the Earth 29:1069-1073. DOI: 
821

822

823

824

825

826

827

828

829

830

831

832

833

834

835

836

837

838

839

840

841

842

843

844

845

846

847

848

849

850

851

852

853

854

855

856

857

858

859

860

10.1016/j.pce.2004.08.008.

Mupangwa W, Love D, Twomlow S. 2006. Soil - water conservation and rainwater harvesting strategies in the semi-arid Mzingwane Catchment, Limpopo Basin, Zimbabwe. 31:893-900. DOI: 10.1016/j.pce.2006.08.042.

Mutiso MP. 2018. Effect of fertilizer microdosing and in situ moisture conservation on yield and resource use efficiency of pearl millet in Makueni County-Kenya (Doctoral dissertation, University of Nairobi).

Mwango SB, Msanya BM, Mtakwa PW, Kimaro DN, Deckers J, Poesen J. 2016. Effectiveness OF Mulching Under Miraba in Controlling Soil Erosion, Fertility Restoration and Crop Yield in the Usambara Mountains, Tanzania. Land Degradation \& Development 27:12661275. DOI: 10.1002/1dr.2332.

Ndlangamandla MT, Ndlela ZP, Manyatsi AM. 2016. Mulching and Tied Ridges as A Moisture Conservation Strategy to Improve the Yield of Sorghum ( Sorghum Bicolor ) in Semi-Arid Parts of Swaziland. International Journal of Environmental \& Agriculture Research (IJOEAR) 2:23-26.

Nooker EP. 2014. Impact of management practices on Minnesota's specialty crop production: From biochar to tillage practices. UNIVERSITY OF MINNESOTA.

Nuti RC, Lamb MC, Sorensen RB, Truman CC. 2009. Agronomic and economic response to furrow diking tillage in irrigated and non-irrigated cotton (Gossypium hirsutum L.). Agricultural Water Management 96:1078-1084. DOI: 10.1016/j.agwat.2009.03.006.

Nyamadzawo G, Wuta M, Nyamangara J, Gumbo D. 2013. Opportunities for optimization of infield water harvesting to cope with changing climate in semi-arid smallholder farming areas of Zimbabwe. SpringerPlus 2:1-9. DOI: 10.1186/2193-1801-2-100.

Obia A, Mulder J, Hale SE, Nurida NL, Cornelissen G. 2018. The potential of biochar in improving drainage, aeration, and maize yields in heavy clay soils. PLoS ONE 13:1-15. DOI: 10.1371/journal.pone.0196794.

Okeyo AI, Mucheru-Muna M, Mugwe J, Ngetich KF, Mugendi DN, Diels J, Shisanya CA. 2014. Effects of selected soil and water conservation technologies on nutrient losses and maize yields in the central highlands of Kenya. Agricultural Water Management 137:52-58. DOI: 10.1016/j.agwat.2014.01.014.

Patil SL, Sheelavantar MN. 2004. Effect of cultural practices on soil properties, moisture conservation, and grain yield of winter sorghum (Sorghum bicolar L. Moench) in semi-arid tropics of India. Agricultural Water Management 64:49-67. DOI: 10.1016/S03783774(03)00178-1.

Peng X, Ye LL, Wang CH, Zhou H, Sun B. 2011. Temperature- and duration-dependent rice straw-derived biochar: Characteristics and its effects on soil properties of an Ultisol in southern China. Soil and Tillage Research 112:159-166. DOI: 10.1016/j.still.2011.01.002.

Prosdocimi M, Tarolli P, Cerdà A. 2016. Mulching practices for reducing soil water erosion: A review. Earth-Science Reviews 161. DOI: 10.1016/j.earscirev.2016.08.006.

Ramakrishna A, Tam HM, Wani SP, Long TD. 2006. Effect of mulch on soil temperature, 
861

moisture, weed infestation, and yield of groundnut in northern Vietnam. Field Crops Research. DOI: 10.1016/j.fcr.2005.01.030.

Rehman HA, Razzaq R. 2017. Benefits of Biochar on the Agriculture and Environment - A Review. Journal of Environmental Analytical Chemistry 04:3-5. DOI: 10.4172/23802391.1000207.

Ren X, Cai T, Chen X, Zhang P, Jia Z. 2016. Effect of rainfall concentration with different ridge widths on winter wheat production under semiarid climate. European Journal of Agronomy 77:20-27. DOI: 10.1016/j.eja.2016.03.008.

Rondon MA, Lehmann J, Ramírez J, Hurtado M. 2007. Biological nitrogen fixation by common beans (Phaseolus vulgaris L.) increases with bio-char additions. Biology and Fertility of Soils 43:699-708. DOI: 10.1007/s00374-006-0152-z.

Ruy S, Findeling A, Chadoeuf J. 2006. Effect of mulching techniques on plot scale runoff: FDTF modeling and sensitivity analysis. Journal of Hydrology 326:277-294. DOI: 10.1016/j.jhydrol.2005.11.003.

Safaei Khorram M, Fatemi A, Khan MA, Kiefer R, Jafarnia S. 2018. Potential risk of weed outbreak by increasing biochar's application rates in slow-growth legume, lentil ( Lens culinaris Medik.). Journal of the Science of Food and Agriculture 98:2080-2088. DOI: $10.1002 /$ jsfa. 8689 .

Sibhatu B, Berhe H, Gebrekorkos G, Abera K. 2017. Effect of Tied Ridging and Fertilizer on the Productivity of Sorghum [Sorghum Bicolor (L.)Moench] at Raya Valley, Northern Ethiopia. Current Agriculture Research Journal 5:396-403. DOI: 10.12944/carj.5.3.20.

Silayo V, Yustas Y, Munder S, Uckert G, Muller J, Elly N, Kimaro A, Mpanda M, Hoffmann H. 2016. UPS 2 : Pyrolysis for energy and biochar production in rural areas.

Silungwe F, Graef F, Bellingrath-Kimura S, Tumbo S, Kahimba F, Lana M. 2019. Analysis of Intra and Interseasonal Rainfall Variability and Its Effects on Pearl Millet Yield in a Semiarid Agroclimate: Significance of Scattered Fields and Tied Ridges. Water (Switzerland) 11:578. DOI: 10.3390/w11030578.

Solaiman ZM, Anawar HM. 2015. Application of Biochars for Soil Constraints: Challenges and Solutions. Pedosphere 25:631-638. DOI: 10.1016/S1002-0160(15)30044-8.

Sumeriya HK, Singh P, Kaushik MK. 2014. Effect of in situ soil moisture conservation practices and its interaction with nutrients in yield, quality, and economics of sorghum [Sorghum bicolor (L.) moench]. Annals of Agri Bio Research 19:234-238.

Trimble SW, Crosson P. 2000. U.S. soil erosion rates - Myth and reality. Science 289:248-250. DOI: $10.1126 /$ science.289.5477.248.

Twomlow SJ, Bruneau PMC. 2000. The influence of tillage on semi-arid soil-water regimes in Zimbabwe. Geoderma 95:33-51. DOI: 10.1016/S0016-7061(99)00071-3.

Vaccari FP, Maienza A, Miglietta F, Baronti S, Di Lonardo S, Giagnoni L, Lagomarsino A, Pozzi A, Pusceddu E, Ranieri R, Valboa G, Genesio L. 2015. Biochar stimulates plant growth but not fruit yield of processing tomato in a fertile soil. Agriculture, Ecosystems and Environment 207:163-170. DOI: 10.1016/j.agee.2015.04.015. 
901

902

903

904

905

906

907

908

909

910

911

912

913

914

915

916

917

918

919

920

921

922

923

924

925

926

927

928

929

930

931

932

933

934

935

936

937

938

939

940

Vega JA, Fernández C, Fonturbel T. 2015. Comparing the effectiveness of seeding and mulching+seeding in reducing soil erosion after a high severity fire in Galicia (NW Spain). Ecological Engineering 74:206-212. DOI: 10.1016/j.ecoleng.2014.10.019.

Vejchar D, Vacek J, Hájek D, Bradna J, Kasal P, Svobodová A. 2019. Reduction of surface runoff on sloped agricultural land in potato cultivation in de-stoned soil. Plant, Soil and Environment 65:118-124. DOI: 10.17221/736/2018-PSE.

Walker S, Tsubo M, Hensley M. 2005. Quantifying risk for water harvesting under semi-arid conditions Part II . Crop yield simulation. 76:94-107. DOI: 10.1016/j.agwat.2005.01.007.

Wallace J. 2000. Increasing agricultural water use efficiency to meet future food production. Agriculture, Ecosystems \& Environment 82:105-119. DOI: 10.1016/S0167-8809(00)002206.

Wang J, Huang J, Zhao X, Wu P, Horwath WR, Li H, Jing Z, Chen X. 2016a. Simulated Study on Effects of Ground Management on Soil Water and Available Nutrients in Jujube Orchards. Land Degradation \& Development 27:35-42. DOI: 10.1002/1dr.2334.

Wang J, Xiong Z, Kuzyakov Y. 2016. Biochar stability in soil: Meta-analysis of decomposition and priming effects. GCB Bioenergy 8:512-523. DOI: 10.1111/gcbb.12266.

Wang Q, Li F, Zhang D, Liu Q, Li G, Liu X, Li X, Chen J. 2018. Sediment control and fodder yield increase in alfalfa (Medicago sativa L) production with tied-ridge-furrow rainwater harvesting on sloping land. Field Crops Research 225:55-63. DOI: 10.1016/j.fcr.2018.05.017.

Wang X, Jia Z, Liang L. 2015. Effect of straw incorporation on the temporal variations of water characteristics, water-use efficiency, and maize biomass production in semi-arid China. Soil and Tillage Research 153:36-41. DOI: 10.1016/j.still.2015.04.011.

Wang X, Li J, Tahir MN, Fang X. 2012. Validation of the EPIC model and its utilization to research the sustainable recovery of soil desiccation after alfalfa (Medicago sativa L.) by grain crop rotation system in the semi-humid region of the Loess Plateau. Agriculture, Ecosystems \& Environment 161:152-160. DOI: 10.1016/j.agee.2012.07.013.

Wang ZJ, Jiao JY, Rayburg S, Wang QL, Su Y. 2016b. Soil erosion resistance of "Grain for Green" vegetation types under extreme rainfall conditions on the Loess Plateau, China. Catena 141:109-116. DOI: 10.1016/j.catena.2016.02.025.

Wiyo K., Kasomekera Z., Feyen J. 2000. Effect of tied-ridging on soil water status of a maize crop under Malawi conditions. Agricultural Water Management 45:101-125. DOI: 10.1016/S0378-3774(99)00103-1.

Woldegiorgis BG. 2017. Effect of Water Harvesting Techniques on Hydrological Processes and Sediment Yield in Northern Ethiopia Berhane Grum Woldegiorgis (Doctoral dissertation, Wageningen University).

Woolf D, Amonette JE, Street-Perrott FA, Lehmann J, Joseph S. 2010. Sustainable biochar to mitigate global climate change. Nature Communications 1:56. DOI: 10.1038/ncomms1053.

Woolf D, Lehmann J, Cowie A, Cayuela ML, Whitman T, Sohi S. 2018. 8 Biochar for Climate Change Mitigation: Navigating from Science to Evidence-Based Policy. Soil and 
961

962

963

964

965

966

967

968

969

970

971

972

973

974

975

976

977

978

979

980

Climate:219-248.

Woolf D, Lehmann J, Lee DR. 2016. Optimal bioenergy power generation for climate change mitigation with or without carbon sequestration. Nature Communications 7:1-11. DOI: 10.1038/ncomms13160.

Xia L, Liu G, Ma L, Yang L, Li Y. 2014. The effects of contour hedges and reduced tillage with ridge furrow cultivation on nitrogen and phosphorus losses from sloping arable land. Journal of Soils and Sediments 14:462-470. DOI: 10.1007/s11368-013-0824-X.

Xiao H, Li Z, Chang X, Huang J, Nie X, Liu C, Liu L, Wang D, Dong Y, Jiang J. 2017. Soil erosion-related dynamics of soil bacterial communities and microbial respiration. Applied Soil Ecology 119:205-213. DOI: 10.1016/j.apsoil.2017.06.018.

Xiao Q, Zhu L xia, Shen Y fang, Li S qing. 2016. Sensitivity of soil water retention and availability to biochar addition in rainfed semi-arid farmland during a three-year field experiment. Field Crops Research 196:284-293. DOI: 10.1016/j.fcr.2016.07.014.

Xiao Q, Zhu L-X, Zhang H-P, Li X-Y, Shen Y-F, Li S-Q. 2016. Soil amendment with biochar increases maize yields in a semi-arid region by improving soil quality and root growth. Crop and Pasture Science 67:495. DOI: 10.1071/CP15351.

Xiaolong R, Zhikuan J, Xiaoli C, Qingfang H, Rong L. 2008. Effects of a rainwater-harvesting furrow/ridge system on spring corn productivity under simulated rainfalls. Acta Ecologica Sinica 28:1006-1015. DOI: 10.1016/S1872-2032(08)60034-7.

Xu G, Zhang Y, Sun J, Shao H. 2016. Negative interactive effects between biochar and phosphorus fertilization on phosphorus availability and plant yield in saline sodic soil. Science of the Total Environment 568:910-915. DOI: 10.1016/j.scitotenv.2016.06.079.

Yoseph T. 2014. Evaluation of Moisture Conservation Practices, Inter and Intra Row Spacing on Yield and Yield Components of Pearl Millet ( Pennisetum glaucum ) at Alduba, Southern Ethiopia. Journal of Natural Sciences Research 4:79-85.

Zelelew DG, Ayimute TA, Melesse AM. 2018. Evaluating the Response of In Situ Moisture Conservation Techniques in Different Rainfall Distributions and Soil-Type Conditions on Sorghum Production and Soil Moisture Characteristics in Drought-Prone Areas of Northern Ethiopia. Water Conservation Science and Engineering 3:157-167. DOI: 10.1007/s41101018-0045-7.

Zhang M, Cheng G, Feng H, Sun B, Zhao Y, Chen H, Chen J, Dyck M, Wang X, Zhang J, Zhang A. 2017a. Effects of straw and biochar amendments on aggregate stability, soil organic carbon, and enzyme activities in the Loess Plateau, China. Environmental Science and Pollution Research 24:10108-10120. DOI: 10.1007/s11356-017-8505-8.

Zhang S, Li P, Yang X, Wang Z, Chen X. 2011. Effects of tillage and plastic mulch on soil water, growth, and yield of spring-sown maize. Soil and Tillage Research 112:92-97. DOI: 10.1016/j.still.2010.11.006.

Zhang F, Zhang W, Li M, Zhang Y, Li F, Li C. 2017b. Is crop biomass and soil carbon storage sustainable with long-term application of full plastic film mulching under future climate change? Agricultural Systems 150:67-77. DOI: 10.1016/j.agsy.2016.10.011. 
981

982

983

984

985

986

987

988

989

990

991

992

993

994

995

996

997

998

999

1000

1001

1002
Zhao H, Xiong YC, Li FM, Wang RY, Qiang SC, Yao TF, Mo F. 2012. Plastic film mulch for half growing-season maximized WUE and yield of potato via moisture-temperature improvement in a semi-arid agroecosystem. Agricultural Water Management 104:68-78. DOI: 10.1016/j.agwat.2011.11.016.

Zhao J, Ren T, Zhang Q, Du Z, Wang Y. 2016. Effects of Biochar Amendment on Soil Thermal Properties in the North China Plain. Soil Science Society of America Journal 80:11571166. DOI: $10.2136 /$ sssaj2016.01.0020.

Zheng J, Chen J, Pan G, Liu X, Zhang X, Li L, Bian R, Cheng K, Jinwei Z. 2016. Biochar decreased microbial metabolic quotient and shifted community composition four years after a single incorporation in a slightly acid rice paddy from southwest China. Science of the Total Environment 571:206-217. DOI: 10.1016/j.scitotenv.2016.07.135.

Zheng J, Fan J, Zhang F, Yan S, Wu Y, Lu J, Guo J, Cheng M, Pei Y. 2019. Throughfall and stemflow heterogeneity under the maize canopy and its effect on soil water distribution at the row scale. Science of The Total Environment 660:1367-1382. DOI: 10.1016/j.scitotenv.2019.01.104.

Zhu Q, Peng X, Huang T. 2015. Contrasted effects of biochar on maize growth and N use efficiency depending on soil conditions. International Agrophysics 29:257-266. DOI: 10.1515/intag-2015-0023.

Zougmoré R, Zida Z, Kambou NF. 2003. Role of nutrient amendments in the success of halfmoon soil and water conservation practice in semiarid Burkina Faso. 71:143-149. DOI: 10.1016/S0167-1987(03)00050-3. 


\section{Table 1 (on next page)}

Soil physical and chemical properties in the experimental field 
Table 1. Soil physical and chemical properties in the experimental field

\begin{tabular}{|c|c|c|c|c|c|c|c|c|c|c|}
\hline $\begin{array}{l}\text { Depth } \\
\text { (cm) }\end{array}$ & $\begin{array}{l}\text { Bulk density } \\
\left(\mathrm{g} \mathrm{cm}^{-3}\right)\end{array}$ & $\begin{array}{l}\text { Field } \\
\text { capacity }(\%)\end{array}$ & $\begin{array}{l}\text { Total N } \\
\left(\mathrm{g} \mathrm{kg}^{-1}\right)\end{array}$ & $\begin{array}{l}\text { Total P } \\
\left(\mathrm{g} \mathrm{kg}^{-1}\right)\end{array}$ & $\begin{array}{l}\text { Total K } \\
\left(\mathrm{g} \mathrm{kg}^{-1}\right)\end{array}$ & $\begin{array}{l}\text { Organic matter } \\
\left(\mathrm{mg} \mathrm{kg}^{-1}\right)\end{array}$ & $\begin{array}{l}\text { Available } \mathrm{N} \\
\left(\mathrm{mg} \mathrm{kg}^{-1}\right)\end{array}$ & $\begin{array}{l}\text { Olsen P } \\
\left(\mathrm{mg} \mathrm{kg}^{-1}\right)\end{array}$ & $\begin{array}{l}\text { Available } \\
\mathrm{K}\left(\mathrm{mg} \mathrm{kg}^{-1}\right)\end{array}$ & $\mathrm{pH}$ \\
\hline $0-40$ & 1.09 & 20.0 & 0.62 & 0.76 & 20.70 & 9.56 & 65.75 & 7.78 & 135 & 7.83 \\
\hline $20-40$ & 1.36 & 21.0 & 0.54 & 0.64 & 20.51 & 7.77 & 22.10 & 3.00 & 90 & 7.82 \\
\hline
\end{tabular}

2 


\section{Table 2 (on next page)}

Alfalfa forage yield and water use efficiency (WUE) in tied-ridge-furrow rainwater harvesting with biochar amendment 
Table 2. Alfalfa forage yield and water use efficiency (WUE) in tied-ridge-furrow rainwater harvesting with biochar amendment. 2

\begin{tabular}{|c|c|c|c|c|c|c|c|c|c|c|}
\hline \multirow{3}{*}{$\begin{array}{c}\text { Biochar } \\
\text { amendment } \\
\text { patterns }\end{array}$} & \multirow{3}{*}{$\begin{array}{c}\text { Tillage } \\
\text { practices }\end{array}$} & \multicolumn{8}{|c|}{ Fodder yield $\left(\mathrm{kg} \mathrm{ha}^{-1}\right)$} & \multirow{3}{*}{$\begin{array}{c}\text { WUE } \\
\left(\mathrm{kg} \mathrm{ha}^{-1} \mathrm{~m}^{-1}\right)\end{array}$} \\
\hline & & \multicolumn{2}{|c|}{ First cut } & \multicolumn{2}{|c|}{ Second cut } & \multicolumn{2}{|c|}{ Third cut } & \multicolumn{2}{|c|}{ Annual total } & \\
\hline & & NFY & AFY & NFY & AFY & NFY & AFY & NFY & AFY & \\
\hline \multicolumn{11}{|c|}{2020} \\
\hline \multirow{4}{*}{ Biochar } & FP & $1728 \mathrm{c}$ & $1728 \mathrm{c}$ & $1027 \mathrm{c}$ & $1027 \mathrm{c}$ & $487 \mathrm{c}$ & $487 \mathrm{c}$ & $3242 c$ & $3242 c$ & $15.23 \mathrm{c}$ \\
\hline & OR & $5726 b$ & $2679 b$ & $2527 b$ & $1298 \mathrm{a}$ & $1198 \mathrm{a}$ & $597 \mathrm{a}$ & $9451 b$ & $4574 b$ & $28.49 b$ \\
\hline & TR & $5928 \mathrm{a}$ & $2826 a$ & $2648 \mathrm{a}$ & $1283 a$ & $1036 b$ & $572 b$ & $9612 \mathrm{a}$ & $4681 \mathrm{a}$ & $30.87 \mathrm{a}$ \\
\hline & FP & $1628 \mathrm{c}$ & $1628 \mathrm{c}$ & $972 c$ & $972 \mathrm{c}$ & $418 c$ & $418 \mathrm{c}$ & $3018 \mathrm{c}$ & $3018 \mathrm{c}$ & $13.45 \mathrm{c}$ \\
\hline \multirow[t]{2}{*}{ No-Biochar } & OR & $5289 b$ & $2372 \mathrm{a}$ & $2486 a$ & $1185 \mathrm{a}$ & $1013 a$ & $627 \mathrm{a}$ & $8788 b$ & $4184 a$ & $22.49 b$ \\
\hline & $\mathrm{TR}$ & $5387 \mathrm{a}$ & $2267 b$ & $2481 \mathrm{a}$ & $1190 \mathrm{a}$ & $987 b$ & $589 b$ & $8855 \mathrm{a}$ & $4046 b$ & $24.73 a$ \\
\hline \multirow[b]{2}{*}{ Mean } & Biochar & 4461 & 2411 & 2067 & 1203 & 907 & 552 & 7435 & 4166 & 24.86 \\
\hline & $\begin{array}{c}\text { No- } \\
\text { Biochar }\end{array}$ & 4101 & 2089 & 1980 & 1116 & 806 & 545 & 6887 & 3749 & 22.89 \\
\hline
\end{tabular}

3 a NFY (Net fodder yield) was forage yield based on furrow areas (exclude ridge and tied-ridge areas).

4 b AFY (actual fodder yield) was forage yield based on land areas of ridges (include ridge and tied-ridge) and furrows.

$5 \quad{ }^{\mathrm{c}} \mathrm{FP}, \mathrm{OR}$ and TR were flat planting, open ridging and tied-ridging, respectively.

6 d Means within a column followed by the same letters are not significantly different at the 5\% level (Tukey's-b test ANOVA). 
Figure 1

Schematic overview of the experimental program

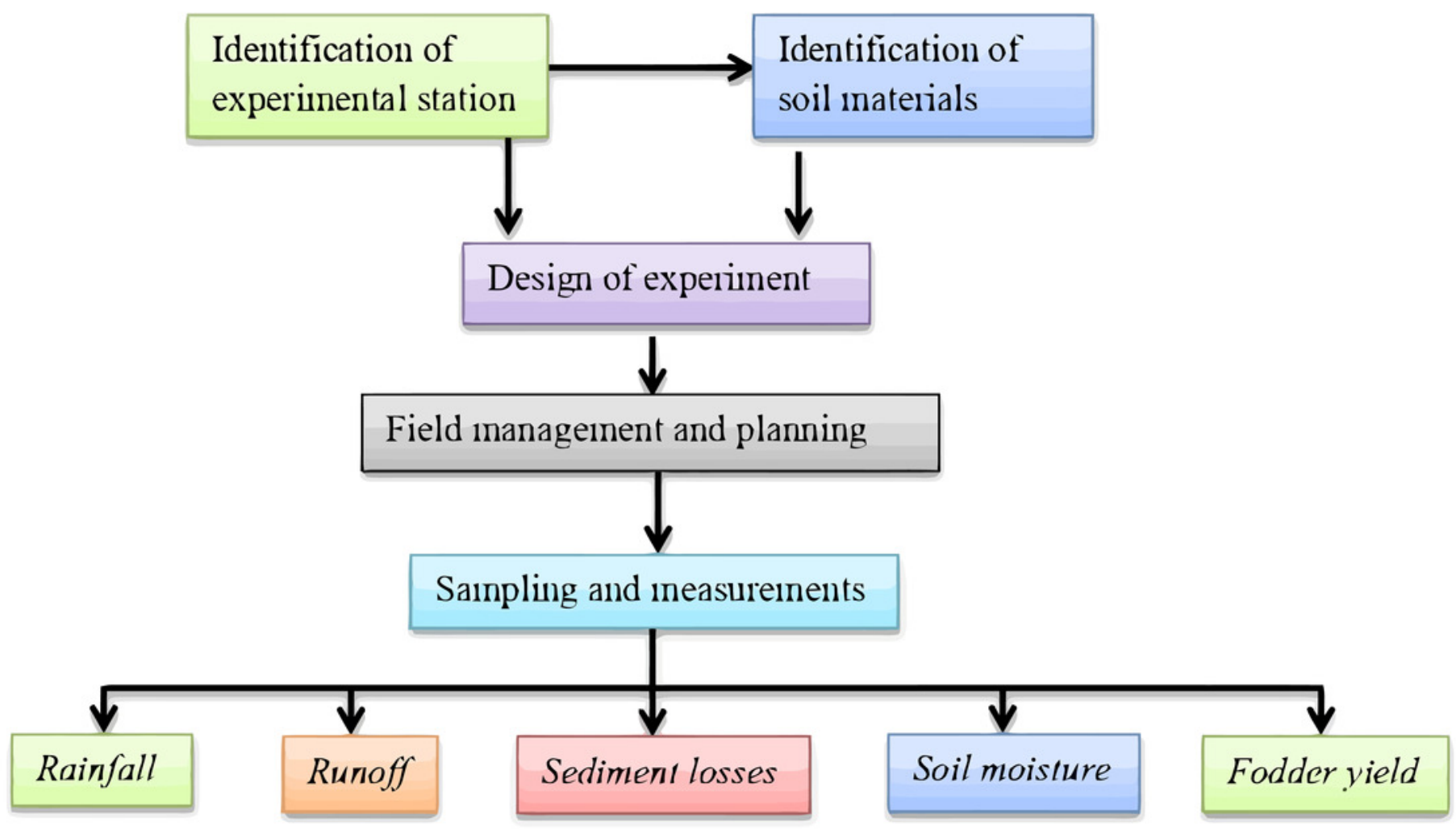


Figure 2

Experimental location of the study. ArcGIS 10.6 software (ESRI, Redlands, California) was used to produce the map.

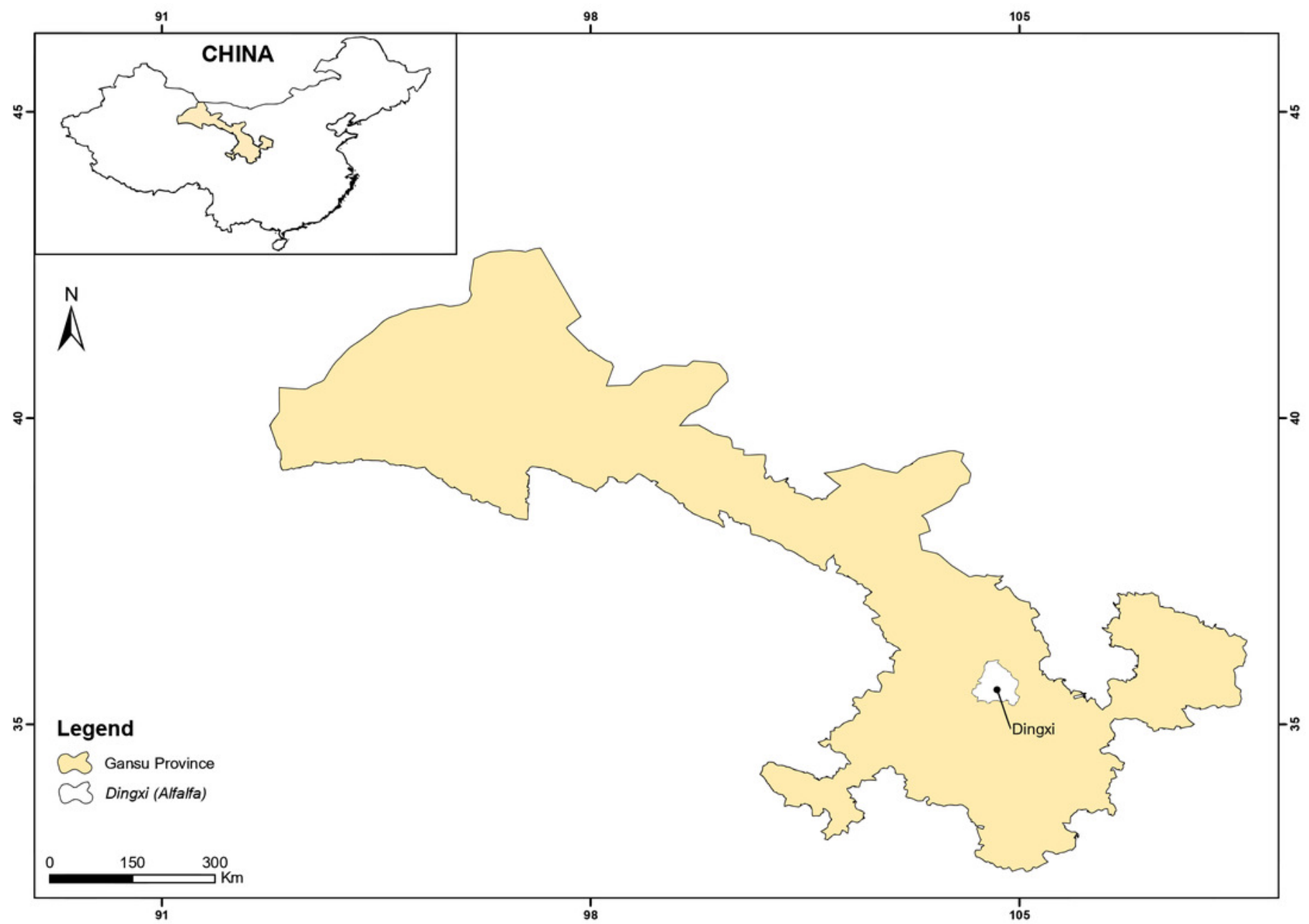


Figure 3

Schematic diagram for alfalfa production in rainwater harvesting system with biochar amendment on sloping land 


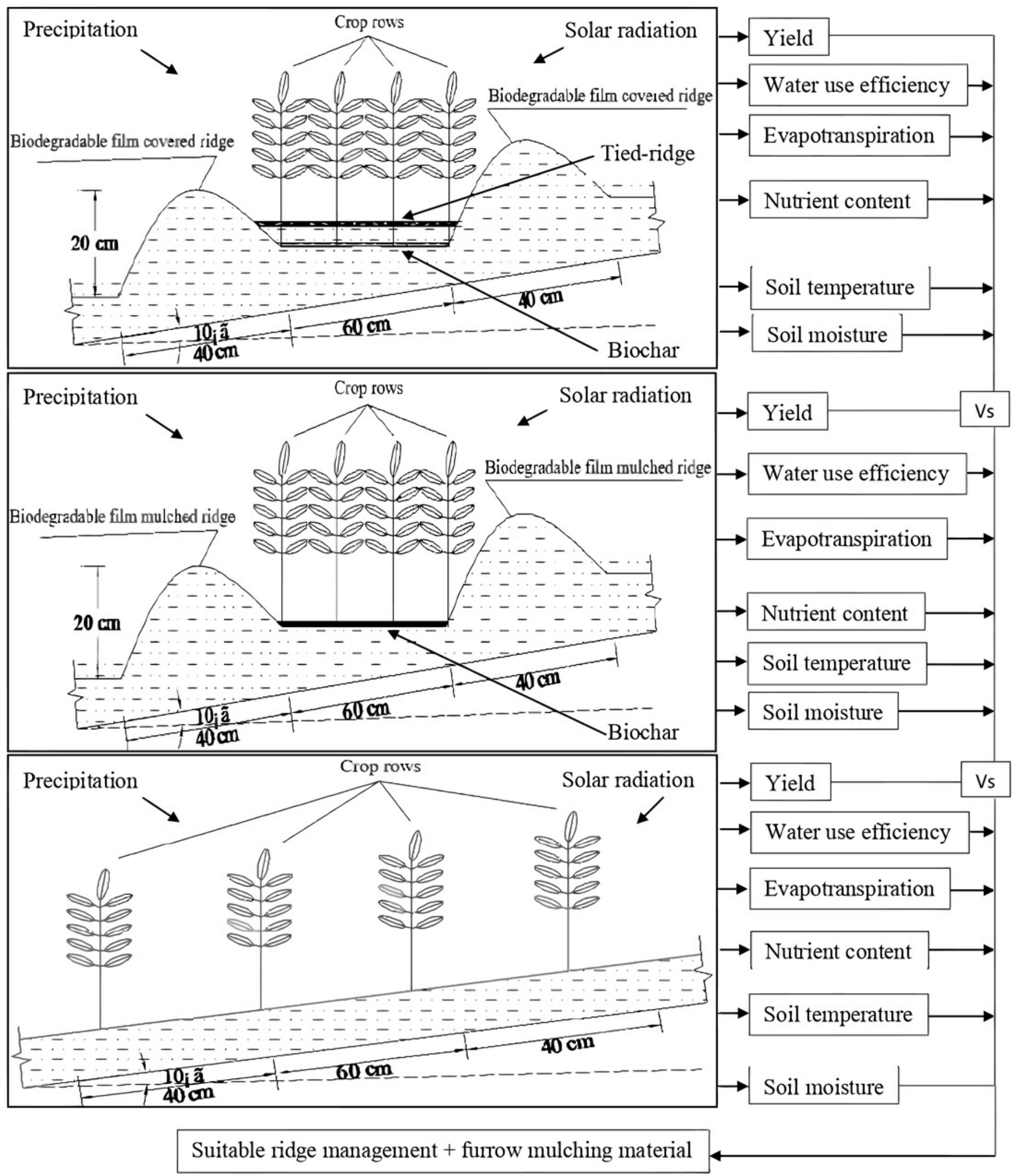


Figure 4

Mean monthly precipitations at the experiment station in 2020

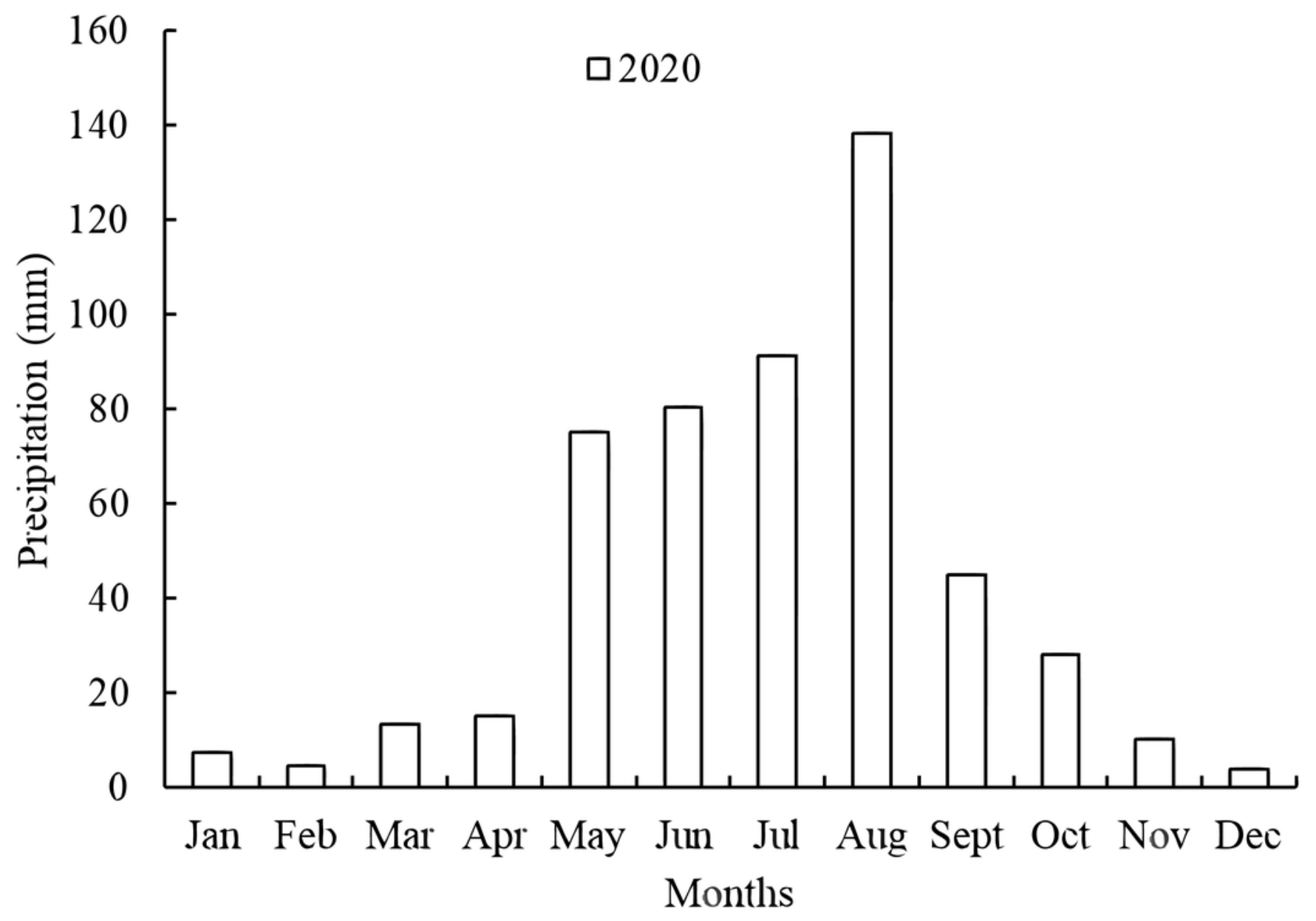


Figure 5

Runoff, runoff efficiency and sediment in different treatments. The means (columns) labeled with the same letters within each category are not significantly different at the $5 \%$ level (Tukey's-b test ANOVA) 

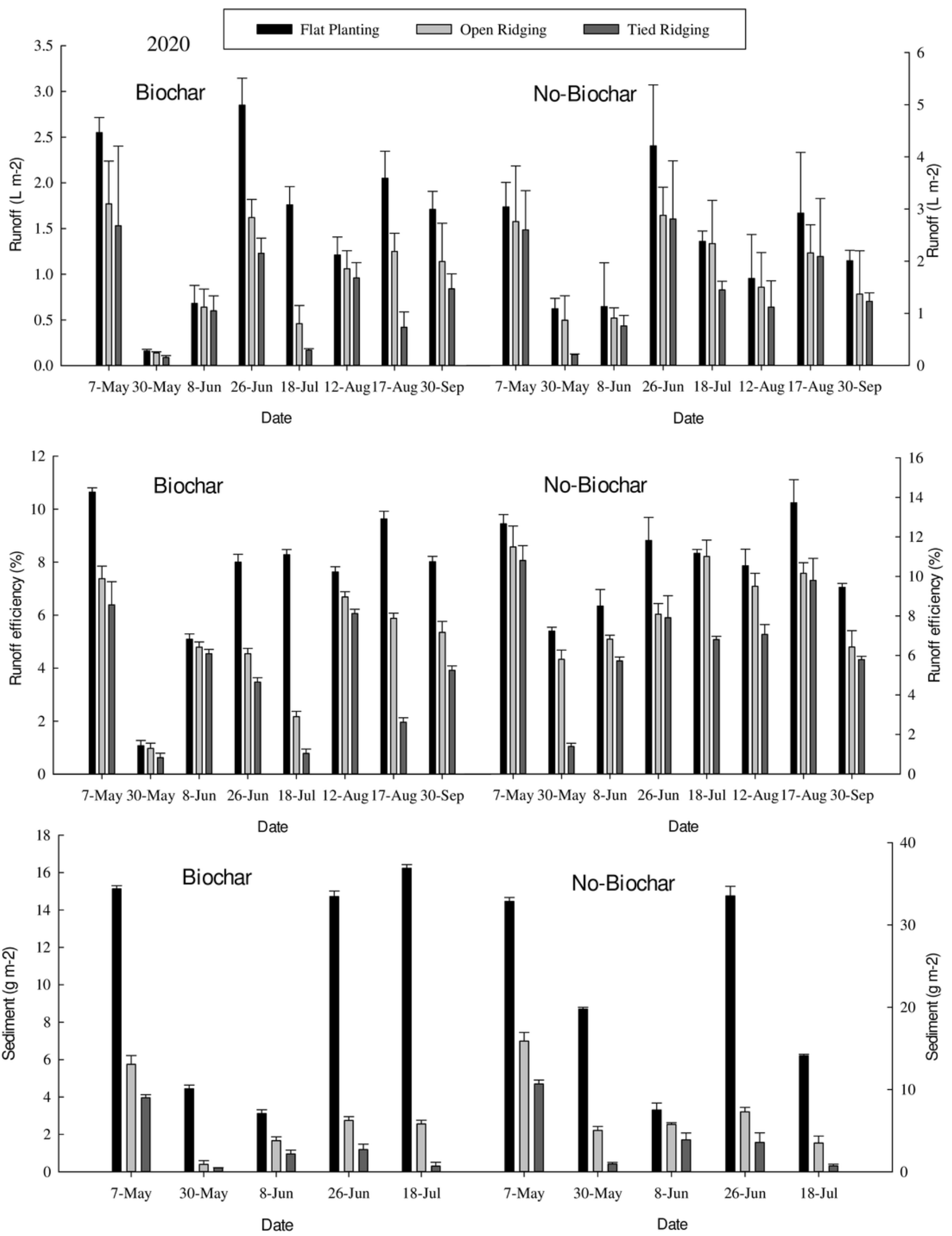
Figure 6

Soil temperatures in furrows and on ridge tops in $0-25 \mathrm{~cm}$ soil depth in various treatments
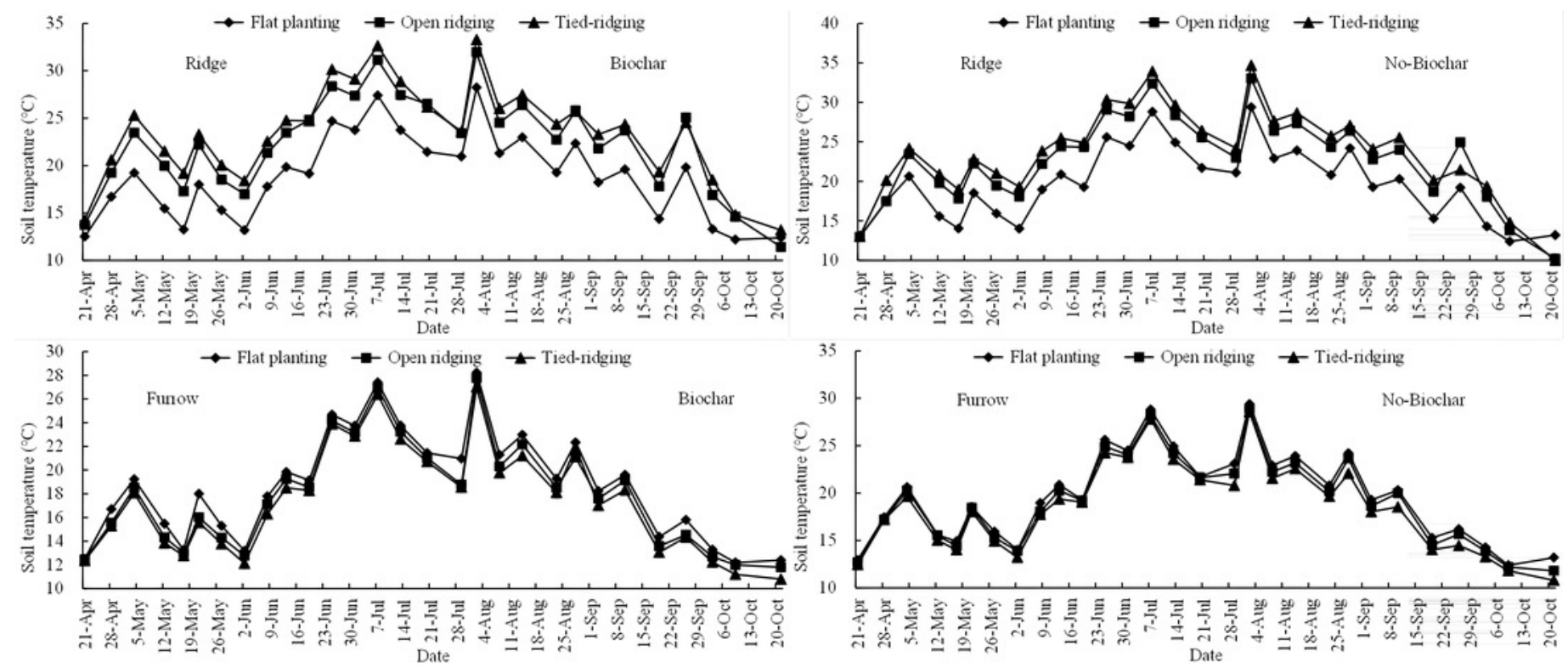
Figure 7

Soil water storage in furrows in $0-200 \mathrm{~cm}$ soil depth in various treatments. The means (columns) labeled with the same letters within each group are not significantly different at the $5 \%$ level (Tukey's-b test ANOVA) 

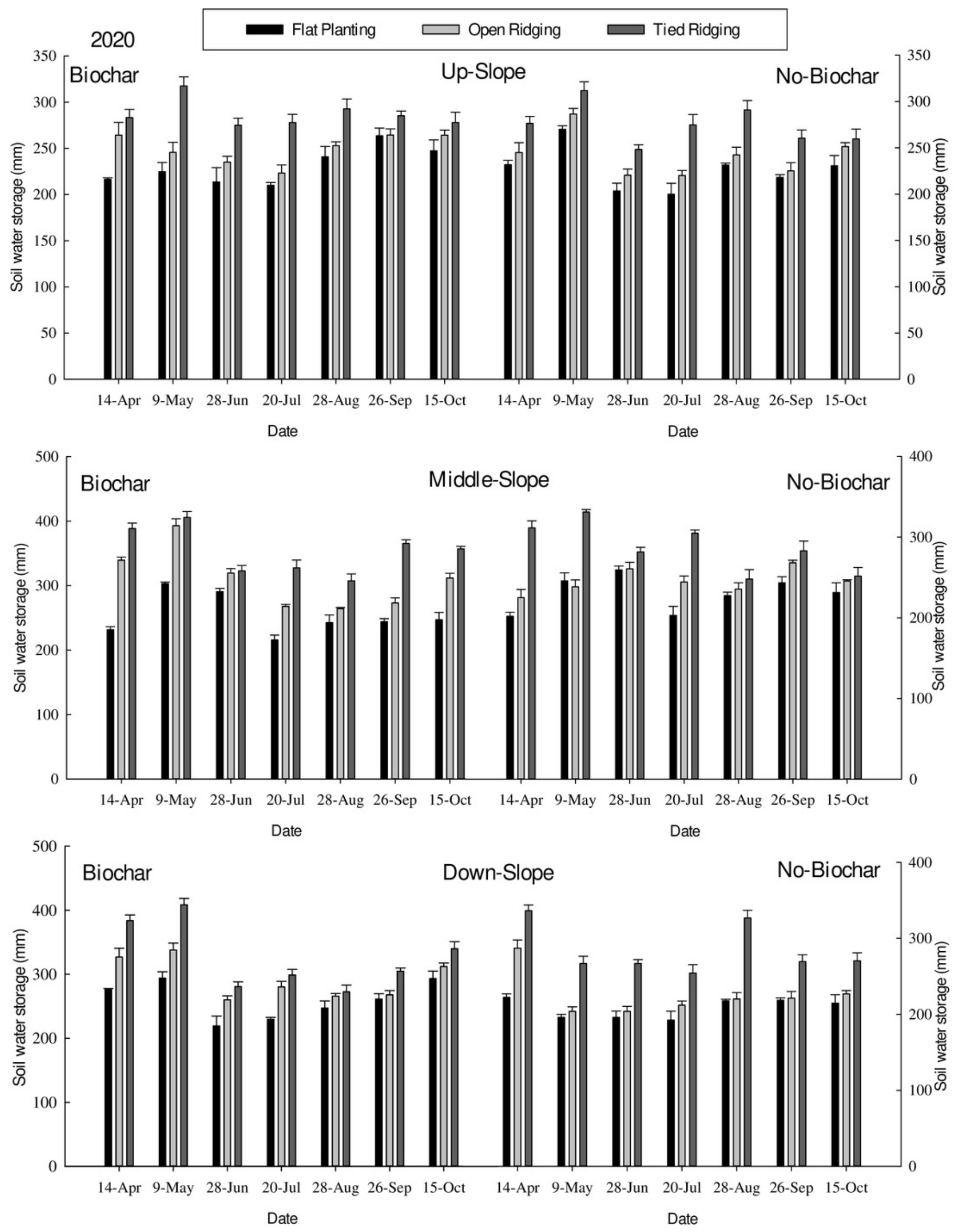